\title{
Solvation Structure and Interfacial Regulation for Extremely Stable Zinc Metal Anodes Operating in a Wide Range of Temperatures
}

\section{Peixun Xiong}

Tianjin University https://orcid.org/0000-0003-0824-1784

\section{Yingbo Kang}

Sungkyunkwan University

Nan Yao

Tsinghua University https://orcid.org/0000-0003-1965-2917

\section{Xiang Chen}

Tsinghua University

\section{Lingxing Zeng}

Fujian Normal University

\section{Qingyun Dou}

Sungkyunkwan University

\section{Xiaotong Han}

Dalian University of Technology

\section{Harpalsinh Rana}

Sungkyunkwan University

\section{Zhenchuan Tian}

Tsinghua University

Jeong Hee Park

Sungkyunkwan University

\section{Qiang Zhang}

Tsinghua University https://orcid.org/0000-0002-3929-1541

Ho Seok Park ( $\square$ phs0727@skku.edu )

Sungkyunkwan University https://orcid.org/0000-0002-4424-4037

\section{Article}

\section{Keywords:}

Posted Date: December 15th, 2021 
License: (c) (i) This work is licensed under a Creative Commons Attribution 4.0 International License. Read Full License 
1 Solvation Structure and Interfacial Regulation for Extremely Stable Zinc Metal Anodes 2 Operating in a Wide Range of Temperatures

3 Peixun Xiong ${ }^{1}$, Yingbo Kang ${ }^{1}$, Nan $\mathrm{Yao}^{2}$, Xiang $\mathrm{Chen}^{2}$, Lingxing Zeng ${ }^{4}$, Qingyun Dou ${ }^{1}$, Xiaotong

4 Han $^{1}$, Rana Harpalsinh ${ }^{1}$, Zhenchuan Tian ${ }^{1}$, Jeong Hee Park ${ }^{1}$, Qiang Zhang ${ }^{2}$, and Ho Seok Park ${ }^{1,3 *}$

$5{ }^{1}$ School of Chemical Engineering, Sungkyunkwan University, Suwon-si, Gyeonggi-do 440-746,

6 Republic of Korea

$7 \quad{ }^{2}$ Beijing Key Laboratory of Green Chemical Reaction Engineering and Technology, Department of 8 Chemical Engineering, Tsinghua University, Beijing, 100084, China

$9{ }^{3}$ SKKU Advanced Institute of Nanotechnology (SAINT), College of Engineering \& Department of 10 Health Sciences and Technology, Samsung Advanced Institute for Health Sciences and Technology 11 (SAIHST), Sungkyunkwan University, 2066, Seobu-ro, Jangan-gu, Suwon-si, Gyeonggi-do 440-746, 12 Republic of Korea

$13{ }^{4}$ Engineering Research Center of Polymer Green Recycling of Ministry of Education, College of 14 Environmental Science and Engineering, Fujian Normal University, Shangsan Road No.8, Fuzhou, 15 350007, People's Republic of China

16 *Email: phs0727@skku.edu (H. S. Park) 


\section{Abstract}

Aqueous zinc-metal batteries are promising for large-scale energy storage owing to their reasonable energy density, safety and low cost. However, their practical applications are limited by hydrogen evolution, corrosion, and dendrite formation of $\mathrm{Zn}$ anode and there is trade-off between efficiency and stability at high and low temperatures. Herein, we propose a solvation chemistry regulation strategy that can adjust the $\mathrm{Zn}^{2+}$-solvation structure and in situ form a robust and $\mathrm{Zn}^{2+}$-conducting $7 \mathrm{Zn}_{5}\left(\mathrm{CO}_{3}\right)_{2}(\mathrm{OH})_{6} \mathrm{SEI}$ on the $\mathrm{Zn}$ surface, using hybrid electrolytes of water and a polar aprotic N, N8 dimethylformamide. As verified by experimental characterizations and computational analyses, the 9 unique solvation structure and the newly formed solid electrolyte interface are created by hybrid 10 electrolytes, resulting in highly reversible and dendrite-free $\mathrm{Zn}$ plating/stripping process as well as 11 thermal stability and high ionic conductivity from -30 to $70{ }^{\circ} \mathrm{C}$. The $\mathrm{Zn}|| \mathrm{Zn}$ symmetric cells in hybrid 12 electrolytes are very stable over $2500 \mathrm{~h}$ at $25{ }^{\circ} \mathrm{C}$ and $2000 \mathrm{~h}$ even at $-20{ }^{\circ} \mathrm{C}$. Thus, the stability and reversibility of the hybrid zinc-ion capacitors with $\mathrm{Zn}$ metal anode in hybrid electrolytes are firstly

14 achieved in a wide and extreme temperature range, demonstrating high capacity retentions and 15 Coulombic efficiencies over 14000,10000 , and 600 cycles at $25,-20$, and $70{ }^{\circ} \mathrm{C}$, respectively. 


\section{Introduction}

Rechargeable aqueous zinc metal batteries (AZMBs) have received significant attention to replace conventional lithium-ion batteries because of the inherent advantages of the zinc ( $\mathrm{Zn})$ metal anodes, including high theoretical gravimetric and volumetric capacities $\left(820 \mathrm{~mA} \mathrm{~h} \mathrm{~g}^{-1}\right.$ and $\left.5855 \mathrm{~mA} \mathrm{~h} \mathrm{~cm}^{-3}\right)$, low cost, and natural abundance ${ }^{1-4}$. Given by the proper plating/stripping potential of $\mathrm{Zn}$ metals, AZMBs further takes advantages in terms of high ionic conductivity and environmental benignity when they are operated in aqueous electrolytes. Despite this harmonized electrochemistry between $\mathrm{Zn}$ metal and aqueous electrolyte, electrochemical performance and stability of AZMBs are deteriorated due to $\mathrm{Zn}$ dendrite formation and corrosion, and hydrogen evolution reaction ${ }^{5-9}$. More critical at higher temperatures $>60{ }^{\circ} \mathrm{C}$ are these unfavorable reactions that can be accelerated by thermal activation, seriously degrading the stability of the batteries ${ }^{10}$. Moreover, the ionic conductivity can be dropped due to water volatilization. On the other hand, even at low temperatures $<0{ }^{\circ} \mathrm{C}$, the reversible deposition/stripping of $\mathrm{Zn}$ metals becomes more sluggish due to the freezing and increased viscosity and salt precipitation ${ }^{11}$. This dilemma limit high efficiency and long-term stability of AZIBs operating in a wide temperature range of "both below $0{ }^{\circ} \mathrm{C}$ and above $60{ }^{\circ} \mathrm{C}$ ".

Herein, we first propose the rational design of hybrid electrolyte regulating solvation structure and interfacial chemistry for highly efficient and stable ZMBs even at low $\left(-30{ }^{\circ} \mathrm{C}\right)$ and high $\left(70{ }^{\circ} \mathrm{C}\right)$ temperatures. Recently, hybrid electrolytes consisting of water and another soluble substance (solid or organic liquid) have been developed to modify the local and/or bulk solvated environment of water for the improved thermodynamic stability ${ }^{12-16}$. Examples of hybrid electrolytes include triethyl phosphate ${ }^{16}$, diethyl ether ${ }^{17}$, ethylene glycol ${ }^{18}$, dimethyl sulfoxide ${ }^{19}$, and acetonitrile ${ }^{20}$ that could enhance the reversibility of $\mathrm{Zn}$ deposition for long term cyclability up to $2000 \mathrm{~h}$ yet being limited by narrow operating temperatures and/or rates $\left(1 \mathrm{~mA} \mathrm{~cm}^{-2}\right.$ and $\left.1 \mathrm{~mA} \mathrm{~h} \mathrm{~cm}^{-2}\right)$.

Our chemical strategy that can overcome these bottlenecks is to simply yet more effectively formulate hybrid electrolytes with a polar aprotic solvent including higher Gutmann donor number than water and in situ solid electrolyte interphase (SEI) forming capability as illustrated by Figure 1. Firstly, this solvent is chosen to disrupt hydrogen bonding networks coordinating with $\mathrm{Zn}^{2+}$, to partially substitute the coordinating $\mathrm{H}_{2} \mathrm{O}$, and finally to modify the solvated structure. Such the modified solvated structure is postulated to increase the $\mathrm{Zn}^{2+}$ de-solvation energy, which leads to regulate the 
1 kinetics for homogeneous $\mathrm{Zn}$ deposition while not seriously slowing the $\mathrm{Zn}^{2+}$ transport $^{16-20}$. Moreover, the $\mathrm{Zn}^{2+}$ transport of solvated structure is persistent even at $-30{ }^{\circ} \mathrm{C}$, where the freezing of $\mathrm{H}_{2} \mathrm{O}$ is inhibited, for a low temperature operation of AZMBs. Secondly, this solvent can be decomposed at the interface to in situ construct a dense and self-repairable SEI onto Zn anode. Thus, the newly formed in situ $\mathrm{Zn}_{5}\left(\mathrm{CO}_{3}\right)_{2}(\mathrm{OH})_{6} \mathrm{SEI}$ is so electrochemically, mechanically, and thermally stable that the dendrite formation can be suppressed at extreme conditions at $70{ }^{\circ} \mathrm{C}$. In order to prove our hypothesis, we chose a polar aprotic N, N-dimethylformamide (DMF) - donor number of 26.6 larger than 18 of $\mathrm{H}_{2} \mathrm{O}^{21}$ and freezing and boiling points of $-61{ }^{\circ} \mathrm{C}$ and $153{ }^{\circ} \mathrm{C}^{22}$ - that can satisfy all of the requirements as discussed above. The superiority of the rationally designed hybrid electrolyte is also confirmed demonstrating highly reversible and dendrite-free $\mathrm{Zn}$ plating/stripping performance of over $2500 \mathrm{~h}$ operated at $25^{\circ} \mathrm{C}\left(1 \mathrm{~mA} \mathrm{~cm}^{-2}\right.$ and $\left.1 \mathrm{~mA} \mathrm{~h} \mathrm{~cm}^{-2}\right)$ and $2000 \mathrm{~h}$ operated at $-20{ }^{\circ} \mathrm{C}\left(0.5 \mathrm{~mA} \mathrm{~cm}^{-2}\right.$ and 0.5 $\mathrm{mA} \mathrm{h} \mathrm{cm}{ }^{-2}$ ) in the $\mathrm{Zn} \| \mathrm{Zn}$ symmetric cells. Furthermore, the hybrid zinc-ion capacitors (HZICs) with hybrid electrolyte are stably operated in a wide temperature range from -30 to $70{ }^{\circ} \mathrm{C}$, achieving a long term cyclability and high Coulombic efficiency.

\section{Results}

\section{Solution structure analysis of electrolyte:}

It has been known that the free water molecules can combine with $\mathrm{Zn}^{2+}$ ions and solvate to form a hydrated zinc ion of $\left[\mathrm{Zn}\left(\mathrm{H}_{2} \mathrm{O}\right)_{6}\right]^{2+}$ in the most common $\mathrm{ZnSO}_{4}$ electrolytes ${ }^{12,23}$. In this study, a series of $2 \mathrm{M} \mathrm{ZnSO}_{4} / \mathrm{H}_{2} \mathrm{O} / \mathrm{DMF}$ hybrid electrolytes with various volume ratios of $\mathrm{H}_{2} \mathrm{O}$ to DMF $(6: 0,5: 1,4: 2$, 3:3, 2:4, 1:5, and 0:6) were prepared (Supplementary Figure 1). Homogenous solutions could be formed when the $\mathrm{H}_{2} \mathrm{O} / \mathrm{DMF}$ ratios were 5:1 and 4:2. However, apparent recrystallization of $\mathrm{ZnSO}_{4}$ occurred when the $\mathrm{H}_{2} \mathrm{O}$ to DMF ratio increased up to 3:3, indicating that DMF was involved in the solvation structure of $\mathrm{Zn}^{2+}$ with water and the excess DMF could damage it (Supplementary Figure 1 and Figure 1) ${ }^{24}$. Although DMF is dissolved in $\mathrm{H}_{2} \mathrm{O}$ in any proportion constructing an hydrogen bonding $(\mathrm{HB})$, it is not readily soluble with $\mathrm{ZnSO}_{4}$ due to an antisolvent against aqueous $\mathrm{ZnSO}_{4}$ electrolyte ${ }^{25,26}$. Accordingly, the $\mathrm{H}_{2} \mathrm{O}$ to DMF ratio is controlled in the range of 6:0 to 2:4.

In order to confirm our strategical hypothesis, the solvation structure of the hybrid electrolytes was investigated by molecular dynamics (MD) simulations and density functional theory (DFT) calculations. The particular number of ions and molecules in the MD simulations box is summarized 
in Supplementary Table 1. The snapshots of the simulated electrolyte structure (Figure 2a, Figure 2c and Supplementary Figure 2) along with the radial distribution functions (RDFs) and coordination number $(\mathrm{CN})$ analyses (Figure 2b, Figure 2d and Supplementary Figure 3) revealed the pronounced ionic solvation cluster for $\mathrm{Zn}^{2+}$ coordinated with $\mathrm{SO}_{4}{ }^{2-}, \mathrm{H}_{2} \mathrm{O}$ and DMF. The RDFs of $\mathrm{ZnSO}_{4}-\mathrm{H}_{2} \mathrm{O}$ electrolyte present that the primary solvation shell of $\mathrm{Zn}^{2+}$ (central ion) is $\sim 2.50 \AA$ in distance (Figure 2b). After the introduction of DMF, distinct $\mathrm{Zn}-\mathrm{O}(\mathrm{DMF})$ pair is observed at $\sim 1.88 \AA$, implying that DMF could be incorporated into the $\mathrm{Zn}^{2+}$-solvation structure (Figure 2d and Supplementary Figure 3). At the increased DMF-to- $\mathrm{H}_{2} \mathrm{O}$ ratio, the $\mathrm{CN}$ of $\mathrm{H}_{2} \mathrm{O}$ in the solvation layer decreases from 3.82 to 3.48, whereas the $\mathrm{CN}$ of DMF increases from 0 to 0.44 , supporting that DMF molecules are participated in the $\mathrm{Zn}^{2+}$-solvation structure (Supplementary Figure 4 and Supplementary Table 2). In addition, new complexes of $\mathrm{Zn}^{2+}[\mathrm{DMF}]_{1}\left[\mathrm{H}_{2} \mathrm{O}\right]_{4}\left[\mathrm{SO}_{4}{ }^{2-}\right]_{1}$ and $\mathrm{Zn}^{2+}[\mathrm{DMF}]_{2}\left[\mathrm{H}_{2} \mathrm{O}\right]_{3}\left[\mathrm{SO}_{4}{ }^{2-}\right]_{1}$ could be found in the hybrid electrolytes (Supplementary Figure 5), which exhibit larger dissociation energies than that of $\mathrm{Zn}^{2+}\left[\mathrm{H}_{2} \mathrm{O}\right]_{5}\left[\mathrm{SO}_{4}{ }^{2-}\right]_{1}$ complex (Figure 2e). The results elucidate that the DMF molecules have a much stronger affinity to the $\mathrm{Zn}^{2+}$ and may significantly change the $\mathrm{Zn}^{2+}$-solvation structure. Meanwhile, the content of $\mathrm{Zn}^{2+}\left[\mathrm{H}_{2} \mathrm{O}\right]_{5}\left[\mathrm{SO}_{4}{ }^{2-}\right]_{1}$ complex also decreases from $65.4 \%$ in $\mathrm{ZnSO}_{4}-\mathrm{H}_{2} \mathrm{O}$ to 51.4\% in $\mathrm{ZnSO}_{4}-\mathrm{H}_{2} \mathrm{O}-\mathrm{DMF}(5: 1)$ and $39.6 \%$ in $\mathrm{ZnSO}_{4}-\mathrm{H}_{2} \mathrm{O}-\mathrm{DMF}$ (4:2), respectively (Supplementary

Figure 5). Furthermore, the relative binding energies of $\mathrm{Zn}^{2+}$ to other species can be ranked in the sequence of $\mathrm{Zn}^{2+}-\mathrm{SO}_{4}{ }^{2-}>\mathrm{Zn}^{2+}-\mathrm{DMF}>\mathrm{Zn}^{2+}-\mathrm{H}_{2} \mathrm{O}$, suggesting that $\mathrm{Zn}^{2+}$ preferentially coordinate with DMF rather than $\mathrm{H}_{2} \mathrm{O}$ (Figure 2f). Hence, the decreased number of coordinating $\mathrm{H}_{2} \mathrm{O}$ would suggest a lower opportunity for side reactions (e.g., HER) during the $\mathrm{Zn}$ deposition process.

In order to further explore the solvation structure of the hybrid electrolytes and the interaction between $\mathrm{ZnSO}_{4}$ and the solvents, various spectroscopic analyses, including nuclear magnetic resonance (NMR), Raman spectrum, and Fourier transform infrared spectroscopy (FTIR) measurements, were conducted. As shown in Figure 2g, ${ }^{67} \mathrm{Zn}$ chemical shift of $\mathrm{ZnSO}_{4}-\mathrm{H}_{2} \mathrm{O}-\mathrm{DMF}$ electrolyte (4.89 ppm) is higher than that of $\mathrm{ZnSO}_{4}-\mathrm{H}_{2} \mathrm{O}$ electrolyte $(4.73 \mathrm{ppm})$, indicating an increased surrounding electron density of $\mathrm{Zn}^{2+}$. This finding suggests that DMF is involved in the solvation sheath and replaces some $\mathrm{H}_{2} \mathrm{O}$ molecules due to the higher donor number of DMF (26.6) than that of $\mathrm{H}_{2} \mathrm{O}(18)^{21}$. Moreover, the ${ }^{17} \mathrm{O}$ chemical shift showed a downshift from 4.56 ppm in $\mathrm{ZnSO}_{4}-\mathrm{H}_{2} \mathrm{O}$ electrolyte to $4.26 \mathrm{ppm}$ in $\mathrm{ZnSO}_{4}-\mathrm{H}_{2} \mathrm{O}-\mathrm{DMF}$ electrolyte, confirming that DMF could be incorporated 
into the solvation structure of $\mathrm{Zn}^{2+}$ with $\mathrm{H}_{2} \mathrm{O}$ (Supplementary Figure 6). The Raman spectra of $\mathrm{H}_{2} \mathrm{O}$ can be resolved into three component bands centered at 3229,3409 , and $3554 \mathrm{~cm}^{-1}$, which are attributed to be symmetric and asymmetric $\mathrm{OH}$ stretching and the free $\mathrm{OH}$ of water, respectively (Figure $2 \mathbf{h})^{25}$. Accordingly, the addition of DMF significantly breaks down the strong HB networks consisting of water as confirmed by the weakened $\mathrm{OH}$ stretching. Consequently, the blue shift of $\mathrm{C}-\mathrm{H}$ stretching for DMF is attributed to the reformation of $\mathrm{HB}$ between the $\mathrm{C}=\mathrm{O}$ group of $\mathrm{DMF}$ and $\mathrm{H}_{2} \mathrm{O}$ molecules. The FTIR spectrum also shows discernible blue-shift in the $\mathrm{OH}$ bending vibration at $1600 \sim 1700 \mathrm{~cm}^{-1}$ and red-shift in the $\mathrm{OH}$ stretching vibration at $3000 \sim 3500 \mathrm{~cm}^{-1}$ of $\mathrm{H}_{2} \mathrm{O}$ as the DMF content increases, verifying the reformation of $\mathrm{HB}$ between DMF and $\mathrm{H}_{2} \mathrm{O}^{25}$. Besides, the blue-shift in the $\mathrm{C}=\mathrm{O}$ bending vibration of DMF $\left(\sim 1661 \mathrm{~cm}^{-1}\right)$ could be observed in the hybrid electrolytes due to the $\mathrm{HB}$ between $\mathrm{C}=\mathrm{O}$ and $\mathrm{H}_{2} \mathrm{O}$. The electrochemical stability windows of various electrolytes were investigated on non-active stain-steel electrodes by linear sweep voltammetry (LSV).

The above calculation (MD and DFT) and experimental (NMR, FTIR, and Raman spectra) results show strong implication on the change of the $\mathrm{Zn}^{2+}$-solvation structure when DMF is incorporated into the electrolyte. As shown in Figure 2i, the $\mathrm{ZnSO}_{4}-\mathrm{H}_{2} \mathrm{O}$ electrolyte undergoes a larger current response compared to the hybrid electrolytes. This result means that the HER is significantly suppressed by DMF addition, further confirming the reformation of $\mathrm{HB}$ arising from the strong interaction between DMF and $\mathrm{H}_{2} \mathrm{O}$. Therefore, the DMF is expected to positively influence the electrodeposition behavior of Zn metal, which further enables a new interface chemistry induced by DMF, as discussed below.

\section{High $\mathrm{Zn} / \mathbf{Z n}^{2+}$ reversibility and uniform $\mathrm{Zn}$ deposits:}

The stability and reversibility of the $\mathrm{Zn}$ anode in $\mathrm{ZnSO}_{4}-\mathrm{H}_{2} \mathrm{O}$ electrolyte with and without DMF were evaluated at a current of $1 \mathrm{~mA} \mathrm{~cm}{ }^{-2}$ and a capacity of $1 \mathrm{~mA} \mathrm{~h} \mathrm{~cm}{ }^{-2}$ using symmetrical $\mathrm{Zn}|| \mathrm{Zn}$ cells (Figure 3a and Supplementary Figure 7). After the initial activation, the symmetric $\mathrm{Zn} \| \mathrm{Zn}$ cells in $\mathrm{ZnSO}_{4}-\mathrm{H}_{2} \mathrm{O}-\mathrm{DMF}\left(\mathrm{H}_{2} \mathrm{O}: \mathrm{DMF}=5: 1\right.$ and 4:2) electrolytes exhibited steady charge/discharge process over 1780 and $2500 \mathrm{~h}$, respectively. By contrast, the $\mathrm{Zn} \mid \mathrm{Zn}$ cell using $\mathrm{ZnSO}_{4}-\mathrm{H}_{2} \mathrm{O}$ electrolyte failed in doing after $92 \mathrm{~h}$ of cycling process due to an internal short circuit arising from $\mathrm{Zn}$ dendrites. The larger overpotential in hybrid electrolytes than that in $\mathrm{ZnSO}_{4}-\mathrm{H}_{2} \mathrm{O}$ electrolyte is attributed to the lower ion conductivity $\left(15.0 \mathrm{mS} \mathrm{cm}{ }^{-1}\right)$ of the former compared to $48.7 \mathrm{mS} \mathrm{cm}^{-1}$ of the latter (Supplementary Figure 8). $\mathrm{ZnSO}_{4}-\mathrm{H}_{2} \mathrm{O}-\mathrm{DMF}$ (4:2) was chosen to evaluate the electrochemical performance at higher 
current densities due to the longer cycle life of the $\mathrm{Zn} \| \mathrm{Zn}$ cell than that with $\mathrm{ZnSO}_{4}-\mathrm{H}_{2} \mathrm{O}-\mathrm{DMF}$ (5:1). As shown in Supplementary Figure 9 and Figure 3b, the $\mathrm{Zn} \| \mathrm{Zn}$ cell in $\mathrm{ZnSO}_{4}-\mathrm{H}_{2} \mathrm{O}-\mathrm{DMF}$ (4:2) electrolyte achieved a stable operating status of over $1400 \mathrm{~h}$ at $2 \mathrm{~mA} \mathrm{~cm}{ }^{-2}$ and $1000 \mathrm{~h}$ at $4 \mathrm{~mA} \mathrm{~cm}{ }^{-2}$, respectively, with the specific capacity of $1 \mathrm{~mA} \mathrm{~h} \mathrm{~cm}{ }^{-2}$. As compared to the cycling performances of symmetrical cells plotting the cumulative capacities of $\mathrm{Zn} \mid \mathrm{Zn}$ cells as shown in Figure 3c (based on the data summarized in Supplementary Table 4), $\mathrm{ZnSO}_{4}-\mathrm{H}_{2} \mathrm{O}-\mathrm{DMF}$ (4:2) electrolyte surpasses the values of most of the previous works at different current densities using the electrolyte optimization strategies $^{12,13,16-20,27-41}$. Figure 3d and Supplementary Figure 10 exhibit the rate capability of the symmetric cells in hybrid and $\mathrm{ZnSO}_{4}-\mathrm{H}_{2} \mathrm{O}$ electrolytes at an area capacity of $1 \mathrm{~mA} \mathrm{~h} \mathrm{~cm}{ }^{-2}$. Although the overpotential of the cells using $\mathrm{ZnSO}_{4}-\mathrm{H}_{2} \mathrm{O}-\mathrm{DMF}$ electrolyte was slightly larger than that in $\mathrm{ZnSO}_{4}-\mathrm{H}_{2} \mathrm{O}$ electrolyte, the former showed a superior rate capability up to $10 \mathrm{~mA} \mathrm{~cm}^{-2}$ and a stable cycle life of over $1000 \mathrm{~h}$ when the current was changed back to $1 \mathrm{~mA} \mathrm{~cm}^{-2}$, whereas the latter revealed short circuits at $4 \mathrm{~mA} \mathrm{~cm}^{-2}$ after cycling at 1 and $2 \mathrm{~mA} \mathrm{~cm}^{-2}$. In addition, $\mathrm{Zn} \| \mathrm{Cu}$ asymmetrical cells were employed to evaluate the Coulombic efficiency (CE) of Zn plating/stripping (Figure 3e). The $\mathrm{Zn}|| \mathrm{Cu}$ cells in hybrid electrolytes exhibit a high average $\mathrm{CE}$ of $99.6 \%$, which is enhanced from $99.0 \%$ within initial cycles due to the formation of robust SEI. Stable voltage curves for Zn plating/stripping, where the separation of charge and discharge potentials decreases initially and is stabilized at $\sim 40 \mathrm{mV}$ after 50 cycles, are observed in $\mathrm{ZnSO}_{4}-\mathrm{H}_{2} \mathrm{O}-\mathrm{DMF}$ electrolyte (Figure 3f). On the other hand, the fluctuated values for $\mathrm{CE}$ and unstable stripping profiles after 80 cycles were found in $\mathrm{ZnSO}_{4}-\mathrm{H}_{2} \mathrm{O}$ electrolyte due to dendrite formation, $\mathrm{H}_{2}$ generation, and the corrosion of $\mathrm{Zn}$ (Supplementary Figure 11).

The greatly improved performance of $\mathrm{Zn}$ anodes is strongly influenced by the suppression of the corrosion reaction of $\mathrm{Zn}$ in the hybrid electrolyte. The $\mathrm{Zn}$ metal in $\mathrm{ZnSO}_{4}-\mathrm{H}_{2} \mathrm{O}-\mathrm{DMF}$ electrolytes shows more positive corrosion potential and decreased corrosion current compared to those in $\mathrm{ZnSO}_{4}$ $\mathrm{H}_{2} \mathrm{O}$ electrolyte, indicating a less tendency of corrosion reactions and a lower corrosion rate of the $\mathrm{Zn}$ electrode in the hybrid electrolyte (Supplementary Figure 12). When $\mathrm{Zn}$ foil was immersed in different electrolytes for 5 days, no discernible change was observed in $\mathrm{ZnSO}_{4}-\mathrm{H}_{2} \mathrm{O}-\mathrm{DMF}$ electrolyte, while numerous scattered flakes were seen in $\mathrm{ZnSO}_{4}-\mathrm{H}_{2} \mathrm{O}$ electrolyte (Supplementary Figures 1314). As shown in the XRD patterns of the immersed $\mathrm{Zn}$ foils in different electrolytes (Supplementary 
Figure 15), the byproduct of corrosion $\left(\mathrm{Zn}_{4} \mathrm{SO}_{4}(\mathrm{OH})_{6} \cdot 3 \mathrm{H}_{2} \mathrm{O}\right)$ is detected in $\mathrm{ZnSO}_{4}-\mathrm{H}_{2} \mathrm{O}$ electrolyte. Pure $\mathrm{Zn}$ phase is solely captured in hybrid electrolytes, confirming their anti-corrosion effect. Moreover, the $\mathrm{Zn} \| \mathrm{Zn}$ symmetrical cell cycled in the hybrid electrolyte exhibited a more stable interface, as supported by the electrochemical impedance spectroscopy (EIS) evolution during cycles (Figures 3g and 3h). Consequently, the charge transfer resistance $\left(R_{c t}\right)$ of the $\mathrm{Zn} \| \mathrm{Zn}$ cells, which is derived from the semicircles in the high-frequency region, is lower in the $\mathrm{ZnSO}_{4}-\mathrm{H}_{2} \mathrm{O}-\mathrm{DMF}$ electrolyte than that in $\mathrm{ZnSO}_{4}-\mathrm{H}_{2} \mathrm{O}$ electrolyte (Supplementary Table 5). In particular, the initial $R_{c t}$ values of the symmetric cells after 30 minutes are gradually reduced after 10 and 20 cycles at $1 \mathrm{~mA} \mathrm{~cm}{ }^{-2}$ and 1 $\mathrm{mA} \mathrm{h} \mathrm{cm}$ in both electrolytes, which is attributed to the better contact between $\mathrm{Zn}$ anodes and electrolyte as cycled (Figures 3g and $\mathbf{3 h}$ ). The enhanced wettability of $\mathrm{Zn}$ foil in the hybrid electrolyte is beneficial for facilitating the $\mathrm{Zn}^{2+}$ flux to the $\mathrm{Zn}$ surface, reducing the charge transfer resistance as well as the Gibbs free energy of the nucleation during the repeat $\mathrm{Zn}$ stripping/plating processes (insets of Figures $3 \mathbf{g}$ and $\mathbf{3 h})^{27}$.

In order to confirm the inhibition effect for $\mathrm{Zn}$ dendrite growth of the hybrid electrolyte, the $\mathrm{Zn}$ deposition morphologies and cross-sectional views in different electrolyte were analyzed using scanning electron microscopy (SEM) and atomic force microscopy (AFM). The $\mathrm{Zn}$ surface in $\mathrm{ZnSO}_{4-}$ $\mathrm{H}_{2} \mathrm{O}$ electrolyte becomes rough with numerous protrusions (dendrites) and scattered flakes (corrosion products) along with a contact angle of $48.4^{\circ}$ after 20 cycles at $1 \mathrm{~mA} \mathrm{~cm}{ }^{-2}$ and $1 \mathrm{~mA} \mathrm{~h} \mathrm{~cm}^{-2}$ (Figures $\mathbf{4 a}$ and $\mathbf{4 b}$ and inset of Figure 3g). Obviously, the smooth dendrite-free morphology and contact angle of $\sim 0^{\circ}$ was obtained for the $\mathrm{Zn}$ cycled in $\mathrm{ZnSO}_{4}-\mathrm{H}_{2} \mathrm{O}-\mathrm{DMF}$ electrolyte (Figures $\mathbf{4 d}$ and $\mathbf{4 e}$ and inset of Figure 3h). Particularly, the AFM altitude intercept of $\mathrm{Zn}$ foil cycled in $\mathrm{ZnSO}_{4}-\mathrm{H}_{2} \mathrm{O}-\mathrm{DMF}$ electrolyte $(621.4 \mathrm{~nm})$ is much lower than that in $\mathrm{ZnSO}_{4}-\mathrm{H}_{2} \mathrm{O}$ electrolyte $(3164.4 \mathrm{~nm})$, which is consistent with the SEM results (Figures $\mathbf{4 c}$ and $\mathbf{4 f}$ ). The direct evidence of regulating Zn plating by DMF addition was obtained from the in situ optical visualization observation (Supplementary Movies 1-2). At $10 \mathrm{~mA} \mathrm{~cm}{ }^{-2}$, the relatively flat $\mathrm{Zn}$ foil in $\mathrm{ZnSO}_{4}-\mathrm{H}_{2} \mathrm{O}$ electrolyte in the initial state became uneven and odd after 10 min of deposition, along with discernible gas bubble on the surface (Figure 4g). On the other hand, the $\mathrm{Zn}$ foil in $\mathrm{ZnSO}_{4}-\mathrm{H}_{2} \mathrm{O}-\mathrm{DMF}$ electrolyte achieved uniform and compact $\mathrm{Zn}$ deposition without the dendrite formation over time interval of 60 min under the same evaluation condition (Figure 4h). To further understand the Zn deposition behaviors in different electrolytes, 
cyclic voltammetry (CV) and chronoamperometry (CA) characterizations were conducted in $\mathrm{Zn} \| \mathrm{Ti}$ and $\mathrm{Zn} \| \mathrm{Zn}$ symmetric cells, respectively. The nucleation overpotential in $\mathrm{ZnSO}_{4}-\mathrm{H}_{2} \mathrm{O}-\mathrm{DMF}$ electrolyte is $\sim 120 \mathrm{mV}$, which is higher than that in $\mathrm{ZnSO}_{4}-\mathrm{H}_{2} \mathrm{O}$ electrolyte (Supplementary Figure 16). The increased nucleation overpotential is attributed to the strong solvation of $\mathrm{Zn}^{2+}$ in the hybrid electrolyte as revealed by the DFT calculation (Figure 2e). As derived from the Arrhenius equation, the activation energy in $\mathrm{ZnSO}_{4}-\mathrm{H}_{2} \mathrm{O}$ is $58.0 \mathrm{~kJ} \mathrm{~mol}^{-1}$, lower than $66.0 \mathrm{~kJ} \mathrm{~mol}^{-1}$ in $\mathrm{ZnSO}_{4}-\mathrm{H}_{2} \mathrm{O}-\mathrm{DMF}$, indicating a higher energy barrier of $\mathrm{Zn}^{2+}$ deposition in the hybrid electrolyte in accordance with the theoretical calculations (Supplementary Figure 17) ${ }^{42}$. Considering that high nucleation overpotential is associated with the fine-grained $\mathrm{Zn}$ deposits ${ }^{43}$, smaller critical nucleus size for $\mathrm{Zn}$ deposition is predicted in the hybrid electrolyte, as being herewith confirmed experimentally and theoretically. As verified by the CA test, the deposition model in $\mathrm{ZnSO}_{4}-\mathrm{H}_{2} \mathrm{O}$ electrolyte corresponds to a long and rampant $2 \mathrm{D}$ ion diffusion process and rough deposition propagation, showing the continuous increase in current density for more than $800 \mathrm{~s}$ at a constant potential of $-150 \mathrm{mV}$ (Supplementary Figure 18). On the other hand, the CA profile in $\mathrm{ZnSO}_{4}-\mathrm{H}_{2} \mathrm{O}-\mathrm{DMF}$ electrolyte is fitted with a relatively stable $3 \mathrm{D}$ diffusion process after $200 \mathrm{~s}$ of planar diffusion and nucleation process, indicating a short and placid diffusion and smooth deposition ${ }^{43}$.

\section{Chemical composition analysis and formation mechnsim of the SEI layer on $\mathrm{Zn}$ anode:}

SEI formed by the addition of DMF was investigated, using focused ion beam transmission electron microscopy (FIB-TEM), XRD, and FTIR. Herein, all the Zn samples were obtained after 20 cycles at $1 \mathrm{~mA} \mathrm{~cm}^{-2}$ and $1 \mathrm{~mA} \mathrm{~h} \mathrm{~cm}^{-2}$. As shown in Figure 5a, obvious interphase with a thickness of 60 70 $\mathrm{nm}$ was created on the $\mathrm{Zn}$ surface in $\mathrm{ZnSO}_{4}-\mathrm{H}_{2} \mathrm{O}-\mathrm{DMF}$ electrolyte, which serves as an electronically insulating barrier restricting the water decomposition and an ionically conducting layer for the uniform $\mathrm{Zn}^{2+}$ flux. As expected, such interphase was absent from $\mathrm{ZnSO}_{4}-\mathrm{H}_{2} \mathrm{O}$ electrolyte (Supplementary Figure 19). XRD analysis of cycled $\mathrm{Zn}$ foil in $\mathrm{ZnSO}_{4}-\mathrm{H}_{2} \mathrm{O}$ electrolyte demonstrated that $\mathrm{Zn}_{4} \mathrm{SO}_{4}(\mathrm{OH})_{6} \cdot 3 \mathrm{H}_{2} \mathrm{O}$ byproduct was formed on the $\mathrm{Zn}$ surface (Figure $\mathbf{5 b}$ and Supplementary Figure 20). In addition to the peaks of this byproduct, the characteristic peaks of $\mathrm{Zn}_{5}(\mathrm{OH})_{6}\left(\mathrm{CO}_{3}\right)_{2}$ could be detected on the $\mathrm{Zn}$ foil in $\mathrm{ZnSO}_{4}-\mathrm{H}_{2} \mathrm{O}-\mathrm{DMF}$ electrolyte (Figure 5b). In addition, the FTIR spectra in Figure $5 \mathbf{c}$ shows that large amount of $\mathrm{CO}_{3}{ }^{2-}\left(\sim 1500 \mathrm{~cm}^{-1}\right)$ and $\mathrm{OH}^{-}\left(\sim 3800 \mathrm{~cm}^{-1}\right)$ exists in the SEI for 
the $\mathrm{Zn}$ foil cycled in the $\mathrm{ZnSO}_{4}-\mathrm{H}_{2} \mathrm{O}-\mathrm{DMF}$ electrolyte, which is convincing evidence of the presence of $\mathrm{Zn}_{5}(\mathrm{OH})_{6}\left(\mathrm{CO}_{3}\right)_{2}{ }^{44}$.

The detailed structure of SEI formed in the $\mathrm{ZnSO}_{4}-\mathrm{H}_{2} \mathrm{O}-\mathrm{DMF}$ electrolyte was characterized by the time-of-fight secondary ion mass spectrometry (TOF-SIMS) and in-depth X-ray photoelectron spectroscopy (XPS). As shown in Figure 5d, in the negative mode, obvious $\mathrm{OH}^{-}(\mathrm{m} / \mathrm{e}=17), \mathrm{CO}_{3}^{2-}$ $(\mathrm{m} / \mathrm{e}=60)$, and $\mathrm{C}^{-}\left(\mathrm{m} / \mathrm{e}=12\right.$, originating from the decomposition of $\left.\mathrm{CO}_{3}{ }^{2-}\right)$ signals were found at various sputtering depths, which implies the existence of $\mathrm{Zn}_{5}(\mathrm{OH})_{6}\left(\mathrm{CO}_{3}\right)_{2}$ in the SEI. Furthermore, XPS with argon sputtering was conducted to further probe the chemical composition and element depth distribution in SEI. The $\mathrm{C}$ atom signal, as an indicator of $\mathrm{CO}_{3}^{2-}$, is stronger than that of $\mathrm{S}$ atom (an indicator of $\mathrm{SO}_{4}{ }^{2-}$ ) at various etching times (Figure 5e). On the surface (before etching) of SEI in $\mathrm{ZnSO}_{4}-\mathrm{H}_{2} \mathrm{O}-\mathrm{DMF}$ electrolyte, minor $\mathrm{CO}_{3}{ }^{2-}$ specie (12.3\%) was detected as evidenced by the $\mathrm{C} 1 \mathrm{~s}$ spectra in Figure 5f. After etching the surface with $\mathrm{Ar}^{+}$bombardment, the ratio of $\mathrm{CO}_{3}{ }^{2-}$ increased to $17.2 \%$ at $10 \mathrm{~min}$ and remained saturated up to $15 \mathrm{~min}$, implying the formation of a $\mathrm{CO}_{3}{ }^{2-}$ contained interphase. Such resistance against etching might be attributed to a very dense surface interphase. The formation of $\mathrm{CO}_{3}{ }^{2-}$ was further confirmed by O-C/O-S signal in the $\mathrm{O} 1 \mathrm{~s}$ spectra at different etching stages (O 1s spectrum in Figure 5f). Besides, the SEI contains large amount of $\mathrm{Zn}-\mathrm{OH}$ and slight $\mathrm{Zn}$ $\mathrm{O}$ as observed in the $\mathrm{Zn} 2 \mathrm{p}_{3 / 2}$ spectrum, which is consistent with the distribution of $\mathrm{OH}$ and $\mathrm{O}^{2-}$ lat signals in $\mathrm{O}$ 1s spectrum.

The formation process of $\mathrm{Zn}_{5}(\mathrm{OH})_{6}\left(\mathrm{CO}_{3}\right)_{2}$ could be proposed in Figure 5g. As $\mathrm{CO}_{3}{ }^{2-}$ was absent in the electrolyte salt $\left(\mathrm{ZnSO}_{4}\right)$, the $\mathrm{CO}_{3}{ }^{2-}$ species were formed from the dissolved $\mathrm{CO}_{2}$ in electrolyte, contributing to the formation of $\mathrm{Zn}_{5}(\mathrm{OH})_{6}\left(\mathrm{CO}_{3}\right)_{2}$. In the $\mathrm{ZnSO}_{4}-\mathrm{H}_{2} \mathrm{O}-\mathrm{DMF}$ electrolyte, the dissolved $\mathrm{CO}_{2}$ and $\mathrm{H}_{2} \mathrm{O}$ reaches the equilibrium in stage $\mathrm{i}^{45}$. Then, the hydrolysis of DMF in stage ii can easily occur due to the acid nature of the electrolyte, thereby producing formic acid $(\mathrm{HCOOH})$ and dimethylamine $\left(\left(\mathrm{CH}_{3}\right)_{2} \mathrm{NH}\right)$ while increasing $\mathrm{pH}$ value (Supplementary Figure 21) ${ }^{46}$. In stage iii, the dimethylamine spontaneously reacts with $\mathrm{HCO}_{3}{ }^{-}$under aqueous environment, leading to the production of $\mathrm{CO}_{3}{ }^{2-}$ species as previously demonstrated ${ }^{47}$.

As proven by XRD, FT-IR, TOF-SIMS, and in-depth XPS analyses, $\mathrm{Zn}_{5}(\mathrm{OH})_{6}\left(\mathrm{CO}_{3}\right)_{2}$ is formed in SEI through the chemical reaction between $\mathrm{CO}_{3}{ }^{2-}, \mathrm{OH}^{-}$, and $\mathrm{Zn}^{2+}$. Given by that $\mathrm{Zn} 5(\mathrm{OH})_{6}\left(\mathrm{CO}_{3}\right)_{2}$ is a $\mathrm{Zn}^{2+}$ conductor ${ }^{33,41}$, the fast transport of $\mathrm{Zn}^{2+}$ is guided by interfacial layer as confirmed by the 
decreased $R_{c t}$ in hybrid electrolyte (Supplementary Table 6). Hence, this newly formed SEI allows $\mathrm{Zn}^{2+}$ to be quickly transported while preventing the $\mathrm{Zn}$ surface from water and preventing side reactions (Figure 5h). Based on the above results, the proposed Zn-plating induction mechanism is schematically illustrated in Figure 1. In different manner to $\mathrm{ZnSO}_{4}-\mathrm{H}_{2} \mathrm{O}$ electrolyte provoking corrosion, $\mathrm{HER}$, and dendrite formation, the $\mathrm{ZnSO}_{4}-\mathrm{H}_{2} \mathrm{O}-\mathrm{DMF}$ electrolyte allows the $\mathrm{Zn}$ anode to achieve uniform and dense $\mathrm{Zn}$ deposition for the greatly improved performance, which is attributed to the combined effect of modified solvation structure and interfacial regulation.

\section{Highly stable HZICs operated at wide-range temperature:}

To clarify the superiority of our hybrid electrolyte for practical application, HZICs were fabricated by coupling $\mathrm{Zn}$ anodes with commercial active carbon (AC) cathodes (Figure 6). For comparison, the electrochemical performance of $\mathrm{HZICs}$ with $\mathrm{ZnSO}_{4}-\mathrm{H}_{2} \mathrm{O}$ electrolyte was evaluated under the same condition. CV curves and galvanostatic charge-discharge (GCD) profiles show that both HZICs in two electrolytes exhibit typical Faradaic features originating from the stripping/plating process of $\mathrm{Zn} / \mathrm{Zn}^{2+}$ (Figures 6a and $\mathbf{6 b}$ and Supplementary Figure 22). The specific capacity and IR drop of HZICs in $\mathrm{ZnSO}_{4}-\mathrm{H}_{2} \mathrm{O}-\mathrm{DMF}$ were nearly comparable to those of $\mathrm{ZnSO}_{4}-\mathrm{H}_{2} \mathrm{O}$ at $0.2 \mathrm{~A} \mathrm{~g}^{-1}$ despite the lower ion conductivity (Figure 6c and Supplementary Figure 8). Nonetheless, the cycling performance was dramatically improved in hybrid electrolytes. As shown in Figure 6d, the HZICs in $\mathrm{ZnSO}_{4}-\mathrm{H}_{2} \mathrm{O}-\mathrm{DMF}$ demonstrates a long-term stability over 14000 cycles with a CE of nearly $100 \%$ at a high current density of $2 \mathrm{~A} \mathrm{~g}^{-1}$. On the other hand, the capacity decay was severe in $\mathrm{ZnSO}_{4}-\mathrm{H}_{2} \mathrm{O}$, and the CEs are quickly dropped after 3000 cycles indicating the formation of dead $\mathrm{Zn}$. As demonstrated by the morphology of the $\mathrm{Zn}$ anodes after 500 cycles in SEM (Supplementary Figure 23), massive protrusions were observed on the $\mathrm{Zn}$ anode cycled in $\mathrm{ZnSO}_{4}-\mathrm{H}_{2} \mathrm{O}$, while a smooth dendrite- or voidfree surface was seen in $\mathrm{ZnSO}_{4}-\mathrm{H}_{2} \mathrm{O}-\mathrm{DMF}$.

In comparison to other solvent additives such as dimethyl sulfoxide and acetonitrile, DMF shows a relatively lower freezing point of $-61{ }^{\circ} \mathrm{C}^{22}$. Considering that the $\mathrm{HBs}$ in $\mathrm{ZnSO}_{4}-\mathrm{H}_{2} \mathrm{O}-\mathrm{DMF}$ were destroyed by DMF, hybrid electrolyte is expected to provide an anti-freezing nature at low temperatures ${ }^{48} . \mathrm{ZnSO}_{4}-\mathrm{H}_{2} \mathrm{O}$ starts to be frozen at $-11{ }^{\circ} \mathrm{C}$, while the freezing points of the hybrid electrolytes decrease down to $-18{ }^{\circ} \mathrm{C}$ and $-32{ }^{\circ} \mathrm{C}$ for $\mathrm{ZnSO}_{4}-\mathrm{H}_{2} \mathrm{O}-\mathrm{DMF}$ (5:1 and 4:2), respectively (Supplementary Figure 24). As verified by the temperature-dependent ionic conductivities, the 
conductivity values of $\mathrm{ZnSO}_{4}-\mathrm{H}_{2} \mathrm{O}-\mathrm{DMF}\left(2.8 \mathrm{mS} \mathrm{cm}{ }^{-1}\right)$ and $\mathrm{ZnSO}_{4}-\mathrm{H}_{2} \mathrm{O}\left(1.5 \mathrm{mS} \mathrm{cm}^{-1}\right)$ are reversed at $-20{ }^{\circ} \mathrm{C}$ (Supplementary Figure 25). The digital photos in Figure 6e support that the freezing of $\mathrm{ZnSO}_{4}-\mathrm{H}_{2} \mathrm{O}$ at $-20{ }^{\circ} \mathrm{C}$ is attributed to the sudden drop of ionic conductivity. By contrast, liquid state was preserved for $\mathrm{ZnSO}_{4}-\mathrm{H}_{2} \mathrm{O}-\mathrm{DMF}$ with high ionic conductivity. Accordingly, voltage profiles for $\mathrm{Zn}|| \mathrm{Zn}$ symmetrical cells in $\mathrm{ZnSO}_{4}-\mathrm{H}_{2} \mathrm{O}-\mathrm{DMF}$ were very stable over $2000 \mathrm{~h}$ at $-20{ }^{\circ} \mathrm{C}$ (Figure 6f). Even at $-20{ }^{\circ} \mathrm{C}$, the HZICs reached a high capacity retention of $99 \%$ after 10000 cycles along with high CEs of nearly 100\% (Figure 6g).

In addition to low temperature operation, the high temperature operation in $\mathrm{ZnSO}_{4}-\mathrm{H}_{2} \mathrm{O}-\mathrm{DMF}$ needs to be considered for wide range applications. The thermal stability of $\mathrm{ZnSO}_{4}-\mathrm{H}_{2} \mathrm{O}$ is strengthened by the addition of DMF due to the inhibited evaporation of $\mathrm{H}_{2} \mathrm{O}$ associated with the strong interaction between DMF and $\mathrm{H}_{2} \mathrm{O}$ as confirmed by the DSC test from 25 to $150{ }^{\circ} \mathrm{C}$ (Supplementary Figure 26). At $60^{\circ} \mathrm{C}$, the HZICs using hybrid electrolyte exhibits a much higher reversible capacity of $38.4 \mathrm{~mA} \mathrm{~h}$ $\mathrm{g}^{-1}$ after 1000 cycles at $2 \mathrm{~A} \mathrm{~g} \mathrm{~g}^{-1}$, while the cells cycled in $\mathrm{ZnSO}_{4}-\mathrm{H}_{2} \mathrm{O}$ failed after 570 cycles (Supplementary Figure 27). Even at a high temperature of $70{ }^{\circ} \mathrm{C}$, the HZICs could be well operated in $\mathrm{ZnSO}_{4}-\mathrm{H}_{2} \mathrm{O}$-DMF over 600 cycles, but the capacity in $\mathrm{ZnSO}_{4}-\mathrm{H}_{2} \mathrm{O}$ was abruptly dropped to near zero after 20 cycles (Supplementary Figure 28). When the water in $\mathrm{ZnSO}_{4}-\mathrm{H}_{2} \mathrm{O}$ electrolyte is evaporated at high temperatures, solubility in the electrolyte is lowered for the salt precipitation and chemical activity increases causing undesirable reaction, resulting in degrading cyclic stability and capacity of $\mathrm{HZICs}^{10}$. Moreover, the HZICs with $\mathrm{ZnSO}_{4}-\mathrm{H}_{2} \mathrm{O}-\mathrm{DMF}$ electrolyte are very tolerant of operating a wide range of temperatures from -30 to $70{ }^{\circ} \mathrm{C}$ (Figures $6 \mathbf{h}$ and $6 \mathbf{i}$ ). In the course of the temperature fluctuation, the capacities of $\mathrm{HZICs}$ in $\mathrm{ZnSO}_{4}-\mathrm{H}_{2} \mathrm{O}$ were suddenly dropped at -20 to 70 ${ }^{\circ} \mathrm{C}$ while those in hybrid electrolytes became much higher. The CEs of the HZICs in hybrid electrolytes were $\approx 100 \%$, while cell failure was observed in DMF-free electrolyte when cycled at $-30{ }^{\circ} \mathrm{C}$ and 70 ${ }^{\circ} \mathrm{C}$ (Figure 6i and Supplementary Figure 29). To the best of our knowledge, this is the first record of $\mathrm{Zn}$ metal anode in liquid electrolytes to achieve the outstanding performances and stabilities in a wide-range extreme temperature range.

In order to investigate the stability of the $\mathrm{Zn}$ anode-electrolyte interphase at low and high temperatures, the EIS test was conducted for the $\mathrm{Zn} \| \mathrm{Zn}$ symmetrical cells after 20 cycles at $-20^{\circ} \mathrm{C}$ and $70{ }^{\circ} \mathrm{C}$ with a current of $1 \mathrm{~mA} \mathrm{~cm}^{-2}$ and a capacity of $1 \mathrm{~mA} \mathrm{~h} \mathrm{~cm}$ (Supplementary Figure 30 and 
1 Supplementary Table 6). It notes that the first semicircle $\left(R_{\text {int }}\right)$ is associated with ion adsorption and desorption on the SEI at the high-frequency region, and the other is attributed to the $R_{c t}$ at the mediumfrequency region ${ }^{18}$. The $R_{\text {int }}$ can be fitted with 3077 (at $-20^{\circ} \mathrm{C}$ ) and $8.9 \Omega\left(\right.$ at $70{ }^{\circ} \mathrm{C}$ ), corresponding to an ion conductivity of $1.1 \sim 1.3 \times 10^{-6}$ and $3.8 \sim 4.4 \times 10^{-4} \mathrm{mS} \mathrm{cm}^{-1}$, respectively, which results in guiding uniform $\mathrm{Zn}$ flux and deposition through SEI layers. In order to evaluate the thermal stability of SEI, we synthesized the sheet-like $\mathrm{Zn}_{5}(\mathrm{OH})_{6}\left(\mathrm{CO}_{3}\right)_{2}$ compounds via a facile precipitation method ${ }^{49}$, as characterized by SEM and XRD (Supplementary Figure 31). As shown in TGA (Supplementary Figure 32), the weight loss at below $200{ }^{\circ} \mathrm{C}$ occurs due to the evaporation of adsorbed water, then one endothermic peak is captured at about $250{ }^{\circ} \mathrm{C}$, indicating the thermal decomposition of $\mathrm{Zn}_{5}(\mathrm{OH})_{6}\left(\mathrm{CO}_{3}\right)_{2}\left(\mathrm{Zn}_{5}(\mathrm{OH})_{6}\left(\mathrm{CO}_{3}\right)_{2} \rightarrow 5 \mathrm{ZnO}+2 \mathrm{CO}_{2}+3 \mathrm{H}_{2} \mathrm{O}^{49}\right)$. This decomposition temperature is far beyond the operating temperature of the $\mathrm{HZIC}$ at $70{ }^{\circ} \mathrm{C}$, confirming an outstanding interfacial thermal in hybrid electrolytes are attributed to the following aspects: The modified solvated structure and the newly formed $\mathrm{Zn}_{5}(\mathrm{OH})_{6}\left(\mathrm{CO}_{3}\right)_{2}$ SEIs of the hybrid electrolyte leads to achieve its thermal stability at high temperatures and high ion conductivity at low temperatures.

\section{Discussion}

In summary, we developed a new electrolyte chemistry for Zn metal batteries by adding DMF as a co-solvent in the electrolyte, thus manipulating the solvation structure of $\mathrm{Zn}^{2+}$ and the formation of SEI. Both of experimental and simulation analysis results indicated that the intensified HB of DMF$\mathrm{H}_{2} \mathrm{O}$ and weakened solvation interaction of $\mathrm{Zn}^{2+}$ with $\mathrm{H}_{2} \mathrm{O}$ were realized by the strong solvation effect between DMF and $\mathrm{Zn}^{2+}$. This unique $\mathrm{Zn}^{2+}$ solvation structure promotes the in situ formation of a $\mathrm{Zn}^{2+}$ conducting and robust $\mathrm{Zn}_{5}\left(\mathrm{CO}_{3}\right)_{2}(\mathrm{OH})_{6} \mathrm{SEI}$, which is confirmed by comprehensive characterizations. As a result, this hybrid electrolyte could effectively suppress the parasitic reactions, which enables highly reversible and dendrite-free $\mathrm{Zn}$ plating/stripping performance of over $2500 \mathrm{~h}\left(1 \mathrm{~mA} \mathrm{~cm}{ }^{-2}\right.$ and $\left.1 \mathrm{~mA} \mathrm{~h} \mathrm{~cm}^{-2}\right)$ and $1000 \mathrm{~h} \mathrm{(4} \mathrm{mA} \mathrm{cm}{ }^{-2}$ and $\left.1 \mathrm{~mA} \mathrm{~h} \mathrm{~cm}^{-2}\right)$ in the $\mathrm{Zn} \| \mathrm{Zn}$ symmetric cells. Furthermore, the DMF-contained hybrid electrolyte allows a greatly extended cycling stability in HZICs that couple $\mathrm{Zn}$ anode and $\mathrm{AC}$ cathode when they are operated at a wide operating temperature range from -30 to $70{ }^{\circ} \mathrm{C}$. Thus, this work not only proposes a simple but effective electrolyte modification approach to achieve dendrite-free $\mathrm{Zn}$ anodes for high-performance aqueous zinc-based energy storage devices 
operated at wide-range temperature, but also shows a new electrolyte chemistry which can also guide the design and development of other aqueous electrochemical energy storage systems.

\section{Methods}

Chemical Reagents. Zn foil (250 $\mu \mathrm{m}$ in thickness, $99.9 \%$ trace metals basis, Sigma-Aldrich) was polished with sandpapers and then washed by ethanol before use. $\mathrm{ZnSO}_{4} \cdot 7 \mathrm{H}_{2} \mathrm{O}(99.5 \%$, Junsei Chemical Co.,Ltd.), N, N-Dimethylformamide (DMF, 99.9\%, DAEJUNG), and active carbon (YP50F, Kuraray) were directly used without any further purification.

Preparation of Electrolytes. Firstly, DMF was mixed with deionized water in different volume ratios $\left(1: 5,2: 4,3: 3,4: 2\right.$, and 5:1). And then stoichiometric amount of $2 \mathrm{M} \mathrm{ZnSO}_{4} \cdot 7 \mathrm{H}_{2} \mathrm{O}$ was dissolved in the above solvents by stirring for $12 \mathrm{~h}$. For comparison, the solutions of $2 \mathrm{M} \mathrm{ZnSO}_{4} \cdot 7 \mathrm{H}_{2} \mathrm{O}$ in pure DMF and $\mathrm{H}_{2} \mathrm{O}$ were also prepared. If without any other special emphasis, $\mathrm{ZnSO}_{4}-\mathrm{H}_{2} \mathrm{O}-\mathrm{DMF}$ represents the electrolyte of $2 \mathrm{M} \mathrm{ZnSO}_{4}$ in $\mathrm{H}_{2} \mathrm{O} / \mathrm{DMF}$ (4:2 in volume ratio).

Preparation of $\mathrm{Zn}_{5}(\mathrm{OH})_{6}\left(\mathrm{CO}_{3}\right)_{2}$ compound. $\mathrm{Zn}_{5}(\mathrm{OH})_{6}\left(\mathrm{CO}_{3}\right)_{2}$ were synthesized using a precipitation method. In a typical synthesis procedure, $3 \mathrm{M} \mathrm{NH}_{4} \mathrm{HCO}_{3}$ and $1 \mathrm{M} \mathrm{NH} \mathrm{NH}_{4} \mathrm{OH}$ were mixed under continuous stirring at room temperature for $10 \mathrm{~min}$. Then the mixed solution was dropped into a solution of $3 \mathrm{M} \mathrm{ZnSO} 4$ under continuous stirring at room temperature for $30 \mathrm{~min}$. After that, the resulting white product was collected by filtration, thoroughly washed with deionized water several times, and then dried at $80{ }^{\circ} \mathrm{C}$ for $12 \mathrm{~h}$.

Characterizations. The morphologies were observed on a SEM (Field-emission JEOL JSM-7500F). TEM images were taken using a Zeiss Libra 200 Cs MC TEM tool with an acceleration voltage of $200 \mathrm{kV}$. The TEM sample was prepared via a focused ion beam (FIB, SMI 3050TB) milling and liftoff process, and the ensuing low-kV Ar surface milling was conducted on the thin samples at $700 \mathrm{~V}$ (Fischione Model 1040 NanoMill) for $15 \mathrm{~min}$ as a post treatment to remove damaged surface layer formed on the thin samples caused by heavy Ga ion beam thinning in the FIB system. The crystal structures were identified by XRD analysis performed on an X'Pert Pro X-ray diffractometer 
1 (PANalytical, Almelo, the Netherlands) device operated at $40 \mathrm{kV}$ and $30 \mathrm{~mA}$, using $\mathrm{Cu}-\mathrm{K}_{\alpha}$ radiation

$(\lambda=0.154 \mathrm{~nm})$ as the X-ray source. The surface chemistry was determined by XPS (ESCALAB 250

$\mathrm{Xi}$, Thermo Fisher). The contact angles between $\mathrm{Zn}$ anodes and electrolyte were measured using a liquid-droplet analysis tool (SmartDrop, Femtofab Co., Ltd, Korea). Atomic force microscopy (AFM) test was conducted on AFM (AFM-5000, Hitachi, Tokyo, Japan). The Fourier transform infrared (FTIR) spectra were measured with a Jasco FT/IR6200 spectrophotometer. ${ }^{67} \mathrm{Zn}$ and ${ }^{17} \mathrm{O}$ NMR spectra of electrolyte were obtained using a Bruker Avance-NEO-600 NMR spectrometer (Bruker Corporation, MA, USA). $2 \mathrm{M} \mathrm{Zn}\left(\mathrm{NO}_{3}\right)_{2}$ in $\mathrm{D}_{2} \mathrm{O}$ was used as the reference solution during the testing process of ${ }^{67} \mathrm{Zn}$ NMR. The Raman experiments were conducted in a XperRam C confocal microRaman microscope (NANOBASE Inc., Korea) using a laser excitation wavelength of $532 \mathrm{~nm}$ (laser power for the sample was $2 \mathrm{~mW}$ ). Time-of-flight SIMS (TOF-SIMS) experiments were conducted using a TOF-SIMS 5 (ION-TOF GmbH, Münster, Germany). A pulsed $25 \mathrm{keV} \mathrm{Bi+} \mathrm{primary} \mathrm{ion} \mathrm{source}$ was employed for analysis, and the data were collected in $40 \mu \mathrm{m}^{2}$ areas along the length of the rectangular sample. The dried $\mathrm{Zn}_{5}(\mathrm{OH})_{6}\left(\mathrm{CO}_{3}\right)_{2}$ powders were analyzed using combined thermogravimetry-differential thermal analysis (TG-DTA, Hitachi STA 7300) under air atmosphere with a heating rate of $5^{\circ} \mathrm{C} \mathrm{min}^{-1}$.

Electrochemical Measurements. Corrosion test was carried on an electrochemical workstation of EC-Lab (NEO Science). Linear polarization and chronoamperograms (CAs) measurements were operated with a three-electrode configuration. The corrosion potential and corrosion current were calculated from Tafel fit system in electrochemical workstation. Bare Zn was used as the working electrode and counter electrode, and silver chloride $(\mathrm{Ag} / \mathrm{AgCl})$ electrode as the reference electrode. Electrochemical impedance spectroscopy (EIS) studies were performed at a sinusoidal perturbation of $5 \mathrm{mV}$ and in the frequency range of $1 \mathrm{mHz} 100 \mathrm{kHz}$. Symmetric $\mathrm{Zn} \| \mathrm{Zn}$ cells were assembled to explore the long-term plating/stripping stability of $\mathrm{Zn}$ anodes in different electrolytes with a charge/discharge areal capacity of $1 \mathrm{~mA} \mathrm{~h} \mathrm{~cm}^{-1}$ at different current densities. Also, similar $\mathrm{Zn} \| \mathrm{Ti}$ 
asymmetric cells were carried out to analyze the Coulombic efficiency for Zn plating/stripping process. Galvanostatic cycling tests were conducted with a Maccor battery tester using CR2032-type coin cells. The separator was glass microfiber membrane (Whatman, Grade GF/A).

The ionic conductivity of the electrolytes was measured at different temperatures through EIS with cells consisted of two parallel Pt-plate electrodes $(1 \mathrm{~cm} \times 1 \mathrm{~cm})$. The applied frequency was in the range of $1 \mathrm{mHz} \sim 100 \mathrm{kHz}$ with a sinusoidal perturbation of $5 \mathrm{mV}$. The electrode resistance was obtained from the intercept of Nyquist plot and the ionic conductivity was calculated according to the following equation:

$$
\sigma=\frac{d}{R_{S} S}
$$

where $\sigma\left(\mathrm{S} \mathrm{cm}^{-1}\right)$ is the per unit conductivity, $R_{S}$ is the electrolyte resistance, $d(\mathrm{~cm})$ is the interval distance $(1 \mathrm{~cm})$ between the two Pt-plate electrodes, $S\left(\mathrm{~cm}^{2}\right)$ is electrode area.

The activation energy $\left(E_{a}\right)$ is calculated based on the Arrhenius equation:

$$
\frac{1}{R_{c t}}=A e^{\left(-\frac{E a}{R T}\right)}
$$

where $R_{c t}$ is the charge transfer resistance, $A$ is the preexponential constant, $T$ is the absolute temperature, $R$ is the standard gas constant.

The ion conductivity $(\delta)$ is calculated based on the following equation:

$$
\delta=\frac{L}{R_{\text {int }} S}
$$

where $\delta\left(\mathrm{S} \mathrm{cm}^{-1}\right)$ is the per unit conductivity, $R_{\text {int }}$ is the interfacial resistance, $L(\mathrm{~cm})$ is the thickness of the SEI $(60 \sim 70 \mathrm{~nm}), S\left(\mathrm{~cm}^{2}\right)$ is electrode area.

Hybrid zinc-ion capacitors were fabricated by using bare $\mathrm{Zn}$ foil as anode, active carbon as cathode, and the above prepared aqueous solution as electrolyte. The active carbon ( $80 \mathrm{wt} \%)$ were mixed with acetylene black $(10 \mathrm{wt} \%)$ and polyvinylidene fluoride $(10 \mathrm{wt} \%)$ in $\mathrm{N}$-methyl-2pyrrolidone. The obtained slurry was then casted on Ti foil and dried at $80^{\circ} \mathrm{C}$ in vacuum for $12 \mathrm{~h}$. The mass loading of active material was $\sim 5 \mathrm{mg} \mathrm{cm}^{-2}$. The galvanostatic cycling tests was tested on a 
1 Maccor battery tester in the voltage range of $0.2 \sim 1.8 \mathrm{~V}\left(\mathrm{Zn}^{2+} / \mathrm{Zn}\right)$. Cyclic voltammetry tests were carried on an electrochemical workstation of EC-Lab (NEO Science). Molecular Dynamics Simulations. Molecular dynamics (MD) simulations were conducted using the Large Scale Atomic/Molecular Massively Parallel Simulator (LAMMPS) code and Optimized

$5 \quad$ Potential for Liquid Simulations-all atom (OPLS-AA) force field. Three models were constructed to model the electrolytes with different $\mathrm{DMF} / \mathrm{H}_{2} \mathrm{O}$ ratios as listed in Supplementary Table 1. The number of ions and solvent molecules in each model are listed in Supplementary Table 2. The initial atomic coordinates were generated with Packing Optimization for Molecular Dynamics Simulations (Packmol) program and the final constructions were visualized by VESTA.

For all the molecular dynamics simulations, the time step was fixed to be 1 fs. The temperature was set to be 293 or $263 \mathrm{~K}$ with Nose-Hoover thermostat with a time constant of 1 ps. The electrolyte systems were first equilibrated in NPT ensemble using the Parrinello-Rahman barostat to maintain the pressure of 1 atm with a decay constant of 0.1 ps for 500 ps. After that, a 7-ns production run in NVT ensemble was conducted. Only the final 5-ns was sampled for mean square displacement and radial distribution function (RDF) analyses. in Gaussian (G09) program with parameter hybrid method using the Lee-Yang-Parr correlation 
1 The dissociation energy $\left(\mathrm{E}_{\mathrm{d}}\right)$ of the $\mathrm{Zn}[\mathrm{DMF}]_{\mathrm{x}}\left[\mathrm{H}_{2} \mathrm{O}\right]_{\mathrm{y}}\left[\mathrm{SO}_{4}{ }^{2-}\right]_{\mathrm{z}}$ was calculated by using the following 2 equation:

$$
\mathrm{E}_{\mathrm{d}}\left(\mathrm{Zn}[\mathrm{DMF}]_{\mathrm{x}}\left[\mathrm{H}_{2} \mathrm{O}\right]_{\mathrm{y}}\left[\mathrm{SO}_{4}{ }^{2-}\right]_{\mathrm{z}}\right)=\mathrm{E}_{\mathrm{Zn} 2+}+\mathrm{xE}_{\mathrm{H} 2 \mathrm{O}}+\mathrm{yE}_{\mathrm{DMF}}+\mathrm{zE}_{\mathrm{SO} 42-}-\mathrm{E}_{\mathrm{Zn}[\mathrm{DMF}] \mathrm{x}[\mathrm{H} 2 \mathrm{O}] \mathrm{y}[\mathrm{SO} 42-] \mathrm{z}}
$$
respectively. reasonable request

\section{References}

1. L. Ma, M. Schroeder, O. Borodin, T. Pollard, M. Ding, C. Wang, K. Xu. Realizing high zinc reversibility in rechargeable batteries. Nat. Energy, 5, 743-749, (2020).

\section{Data availability}

The data that support the findings of this study are available from the corresponding author upon

4

2. Y. Liang, H. Dong, D. Aurbach, Y. Yao. Current status and future directions of multivalent metalion batteries. Nat. Energy, 5, 646-656, (2020).

3. N. Zhang, X. Chen, M. Yu, Z. Niu, F. Cheng, J. Chen. Materials chemistry for rechargeable zincion batteries. Chem. Soc. Rev. 49, 4203-4219, (2020).

4. X. Jia, C. Liu, Z. Neale, J. Yang, G. Cao. Active materials for aqueous zinc ion batteries: synthesis, crystal structure, morphology, and electrochemistry. Chem. Rev. 120, 7795-7866, (2020).

5. B. Tang, L. Shan, S. Liang, J. Zhou. Issues and opportunities facing aqueous zinc-ion batteries. Energy Environ. Sci. 12, 3288-3304, (2019). 
6. J. Zheng, L. Archer. Controlling electrochemical growth of metallic zinc electrodes: Toward affordable rechargeable energy storage systems. Sci. $A d v .7$, eabe0219, (2021).

7. L. Blanc, D. Kundu, L. Nazar. Scientific challenges for the implementation of Zn-ion batteries. Joule, 4, 771-799, (2020).

8. W. Du, E. Ang, Y. Yang, Y. Zhang, M. Ye, C. Li. Challenges in the material and structural design of zinc anode towards high-performance aqueous zinc-ion batteries. Energy Environ. Sci. 13, 3330-3360, (2020).

9. Q. Zhang, J. Luan, Y. Tang, X. Ji, H. Wang. Interfacial design of dendrite- free zinc anodes for aqueous zinc- ion batteries. Angew. Chem. Int. Ed. 59, 13180-13191, (2020).

10. H. Wang, Z. Chen, Z. Ji, P. Wang, J. Wang, W. Ling, Y. Huang. Temperature adaptability issue of aqueous rechargeable batteries. Mater. Today Energy, 19, 100577, (2021).

11. Q. Nian, T. Sun, S. Liu, H. Du, X. Ren, Z. Tao. Issues and opportunities on Low-Temperature Aqueous Batteries. Chem. Eng. J. 423, 130253, (2021).

12. F. Wang, O. Borodin, T. Gao, X. Fan, W. Sun, F. Han, A. Faraone, J. A. Dura, K. Xu, C. Wang. Highly reversible zinc metal anode for aqueous batteries. Nat. Mater. 17, 543-549, (2018).

13. A. Bayaguud, X. Luo, Y. Fu, C. Zhu. Cationic surfactant-type electrolyte additive enables threedimensional dendrite-free zinc anode for stable zinc-ion batteries. ACS Energy Lett. 5, 3012-3020, (2020).

14. X. Guo, Z. Zhang, J. Li, N. Luo, G. Chai, T. S. Miller, F. Lai, P. Shearing, D. J. L. Brett, D. Han, Z. Weng, G. He, I. P. Parkin. Alleviation of Dendrite Formation on Zinc Anodes via Electrolyte Additives. ACS Energy Lett. 6, 395-403, (2021). 
15. Y. Xu, J. Zhu, J. Feng, Y. Wang, X. Wu, P. Ma, X. Zhang, G. Wang, X. Yan. A rechargeable aqueous zinc/sodium manganese oxides battery with robust performance enabled by Na2SO4 electrolyte additive. Energy Storage Materials, 38, 299-308, (2021).

16. A. Naveed, H. Yang, J. Yang, Y. Nuli, J. Wang. Highly reversible and rechargeable safe Zn batteries based on a triethyl phosphate electrolyte. Angew. Chem. Int. Ed. 58, 2760-2764, (2019).

17. W. Xu, K. Zhao, W. Huo, Y. Wang, G. Yao, X. Gu, H. Cheng, L. Mai, C. Hu, X. Wang. Diethyl ether as self-healing electrolyte additive enabled long-life rechargeable aqueous zinc ion batteries. Nano Energy, 62, 275-281, (2019).

18. N. Chang, T. Li, R. Li, S. Wang, Y. Yin, H. Zhang, X. Li. An aqueous hybrid electrolyte for lowtemperature zinc-based energy storage devices. Energy Environ. Sci. 13, 3527-3535, (2020).

19. L. Gao, D. Li, E. Hu, J. Xu, T. Deng, L. Ma, Y. Wang, X. Yang, C. Wang. Solvation structure design for aqueous Zn metal batteries. J. Am. Chem. Soc. 142, 21404-21409, (2020).

20. Z. Hou, H. Tan, Y. Gao, M. Li, Z. Lu, B. Zhang. Tailoring desolvation kinetics enables stable zinc metal anodes. J. Mater. Chem. A, $8,19367-19374,(2020)$.

21. V. Gutmann. Empirical parameters for donor and acceptor properties of solvents. Electrochim. Acta, 21, 661-670, (1976).

22. A. K. Covington, T. Dickinson. Introduction and solvent properties. Physical Chemistry of Organic Solvent Systems; Plenum: New York, 1-22, (1973).

23. M. Li, Z. Li, X. Wang, J. Meng, X. Liu, B. Wu, C. Han, L. Mai. Comprehensive Understandings into Roles of Water Molecules in Aqueous Zn-Ion Batteries: From Electrolytes to Electrode Materials. Energy Environ. Sci. 14, 3796-3839, (2021). 
24. T. C. Schutt, G. A. Hegde, V. S. Bharadwaj, A. J. Johns, C. M. Maupin. Impact of water-dilution on the solvation properties of the ionic liquid 1-methyltriethoxy-3-ethylimidazolium acetate for model biomass molecules. J. Phys. Chem. B, 121, 843-853, (2017).

25. B. Yang, H. Lang, Z. Liu, S. Wang, Z. Men, C. Sun. Three stages of hydrogen bonding network in DMF-water binary solution. J. Mol. Liq. 324, 114996, (2021).

26. J. Hao, L. Yuan, C. Ye, D. Chao, K. Davey, Z. Guo, S.-Z. Qiao. Boosting Zinc Electrode Reversibility in Aqueous Electrolytes by Using Low- Cost Antisolvents. Angew. Chem. 133, 74427451, (2021).

27. J. Hao, J. Long, B. Li, X. Li, S. Zhang, S. Zhang, F. Yang, X. Zeng, Z. Yang, W. Pang, Z. Guo. Toward High-Performance Hybrid Zn-Based Batteries via Deeply Understanding Their Mechanism and Using Electrolyte Additive. Adv. Funct. Mater. 29, 1903605, (2019).

28. J. Zhao, J. Zhang, W. Yang, B. Chen, Z. Zhao, H. Qiu, S. Dong, X. Zhou, G. Cui, L. Chen. “ Water-in-deep eutectic solvent" electrolytes enable zinc metal anodes for rechargeable aqueous batteries. Nano Energy, 57, 625-634, (2019).

29. S. Chen, R. Lan, J. Humphreys, S. Tao. Salt-concentrated acetate electrolytes for a high voltage aqueous $\mathrm{Zn} / \mathrm{MnO}_{2}$ battery. Energy Storage Materials, 28, 205-315, (2020).

30. P. Sun, L. Ma, W. Zhou, M. Qiu, Z. Wang, D. Chao, W. Mai. Simultaneous Regulation on Solvation Shell and Electrode Interface for Dendrite- Free Zn Ion Batteries: Achieved by a LowCost Glucose Additive. Angew. Chem. 133, 18395-18403, (2021).

31. X. Zeng, J. Mao, J. Hao, J. Liu, S. Liu, Z. Wang, Y. Wang, S. Zhang, T. Zheng, J. Liu, P. Rao, Z. Guo. Electrolyte Design for In Situ Construction of Highly Zn2+-Conductive Solid Electrolyte 
Interphase to Enable High-Performance Aqueous Zn-Ion Batteries under Practical Conditions. Adv. Mater. 33, 2007416, (2021).

32. L. Ma, T. P. Pollard, Y. Zhang, M. A. Schroeder, M. S. Ding, A. V. Cresce, R. Sun, D. R. Baker, B. A. Helms, E. J. Maginn, C. Wang, O. Borodin, K. Xu. Functionalized Phosphonium Cations Enable Zinc Metal Reversibility in Aqueous Electrolytes. Angew. Chem. Int. Ed. 60, 1243812445, (2021).

33. D. Li, L. Gao, T. Deng, S. Liu, C. Wang. Design of a Solid Electrolyte Interphase for Aqueous Zn Batteries. Angew.Chem. Int.Ed. 60, 13035-13041, (2021).

34. Y. Dong, L. Mao, G. Ma, S. Di, Y. Wang, L. Wang, J. Xu, N. Zhang. Non-concentrated aqueous electrolytes with organic solvent additives for stable zinc batteries. Chem. Sci. 12, 5843-5852, (2021).

35. V. Verma, R. M. Chan, L. Yang, S. Kumar, S. Sattayaporn, R. Chua, Y. Cai, P. Kidkhunthod, W. M. Jr., M. Srinivasan. Chelating Ligands as Electrolyte Solvent for Rechargeable Zinc-Ion Batteries. Chem. Mater. 33, 1330-1340, (2021).

36. Y. Zhu, S. Zhang, S. Wu, Z. Hu, G. Cui, J. Luo. In situ built interphase with high interface energy and fast kinetics for high performance Zn metal anodes. Energy Environ. Sci. 14, 3609-3620, (2021).

37. Y. Zhang, M. Zhu, K. Wu, F. Yu, G. Wang, G. Xu, M. Wu, H. Liu, S. Dou, C. Wu. An in-depth insight of a highly reversible and dendrite-free $\mathrm{Zn}$ metal anode in an hybrid electrolyte. J. Mater. Chem. A, 9, 4253-4261, (2021). 
38. H. Wu, X. Gu, P. Huang, C. Sun, H. Hu. Y. Zhong, C. Lai. Polyoxometalate driven dendrite-free zinc electrodes with synergistic effects of cation and anion cluster regulation. J. Mater. Chem. A, 9, 7025-7033, (2021).

39. R. Qin, Y. Wang, M. Zhang, Y. Wang, S. Ding, A. Song, H. Yi, L. Yang, Y. Song, Y. Cui, J. Liu, Z. Wang, S. Li, Q. Zhao, F. Pan. Tuning $\mathrm{Zn}^{2+}$ coordination environment to suppress dendrite formation for high-performance Zn-ion batteries. Nano Energy, 80, 105478, (2021).

40. C. Sun, C. Wu, X. Gu, C. Wang, Q. Wang. Interface Engineering via $\mathrm{Ti}_{3} \mathrm{C}_{2} \mathrm{~T}_{x} \mathrm{MXene}$ Electrolyte Additive toward Dendrite-Free Zinc Deposition. Nano-Micro Lett. 13, 89, (2021).

41. L. Cao, D. Li, T. Pollard, T. Deng, B. Zhang, C. Yang, L. Chen, J. Vatamanu, E. Hu, M. J. Hourwitz, L. Ma, M. Ding, Q. Li, S. Hou, K. Gaskell, J. T. Fourkas, X.-Q. Yang, K. Xu, O. Borodin, C. Wang. Fluorinated interphase enables reversible aqueous zinc battery chemistries. Nat. Nanotechnol. 16, 902-910, (2021).

42. D. Kundu, S. H. Vajargah, L. Wan, B. Adams, D. Prendergast, L. F. Nazar. Aqueous vs. nonaqueous $\mathrm{Zn}$-ion batteries: consequences of the desolvation penalty at the interface. Energy Environ. Sci. 11, 881-892, (2018).

43. Z. Zhao, J. Zhao, Z. Hu, J. Li, J. Li, Y. Zhang, C. Wang, G. Cui. Long-life and deeply rechargeable aqueous $\mathrm{Zn}$ anodes enabled by a multifunctional brightener-inspired interphase. Energy Environ. Sci. 12, 1938-1949, (2019).

44. J. Hao, B. Li, X. Li, X. Zeng, S. Zhang, F. Yang, S. Liu, D. Li, C. Wu, Z. Guo. An In- Depth Study of $\mathrm{Zn}$ Metal Surface Chemistry for Advanced Aqueous Zn-Ion Batteries. Adv. Mater. 32, 2003021, (2020).

45. T. Loerting, J. Bernard. Aqueous carbonic acid $\left(\mathrm{H}_{2} \mathrm{CO}_{3}\right)$. ChemPhysChem, 11, 2305, (2020). 
46. Z. Kong, L. Li, R. Kurihara, K. Kubota, Y.-Y. Li. Anaerobic treatment of N, Ndimethylformamide-containing wastewater by co-culturing two sources of inoculum. Water Res. 139, 228-239, (2018).

47. F. A. Chowdhury, H, Yamada, T. Higashii, K. Goto, M. Onoda. $\mathrm{CO}_{2}$ Capture by Tertiary Amine Absorbents: A Performance Comparison Study. Ind. Eng. Chem. Res. 52, 8323-8331, (2013).

48. C. X. Zhao, J.-N. Liu, N. Yao, J. Wang, D. Ren, X. Chen, B. Q. Li, Q. Zhang. Can Aqueous Zinc Air Batteries Work at Sub-Zero Temperatures? Angew. Chem. Int. Ed. 133, 15409-15413, (2021).

49. J. Winiarski, W. Tylus, K. Winiarska, I. Szcaygieł, B. Szczygieł. XPS and FT-IR characterization of selected synthetic corrosion products of zinc expected in neutral environment containing chloride ions. J. Spectrosc. 2018, 2079278, (2018).

\section{Acknowledgement}

This research was supported by the financial support from the National Research Foundation of Korea (NRF) grant funded by the Korea government (MSIT) (NRF-2020R1A3B2079803), Republic of Korea.

\section{Author Contributions}

P. X. designed the experiments and analyzed data. Y. Kang, L. Zeng, Q. Dou, X. Han, R. Harpalsinh, Z. Tian, J. H. Park assisted with the material synthesis and characterizations. N. Yao, X. Chen, Q. Zhang conducted the calculations. H. S. P. conceived and supervised the project. All authors contributed to interpretation of the results.

\section{Competing Interests Statement}

The authors declare that they have no competing interests.

\section{Additional Information}

Supplementary information is available for this paper at www.nature.com/nature. 
1 Correspondence and requests for materials should be addressed to H. S. Park.

2 Publisher's note: Springer Nature remains neutral with regard to jurisdictional claims in published 3 maps and institutional affiliations. 

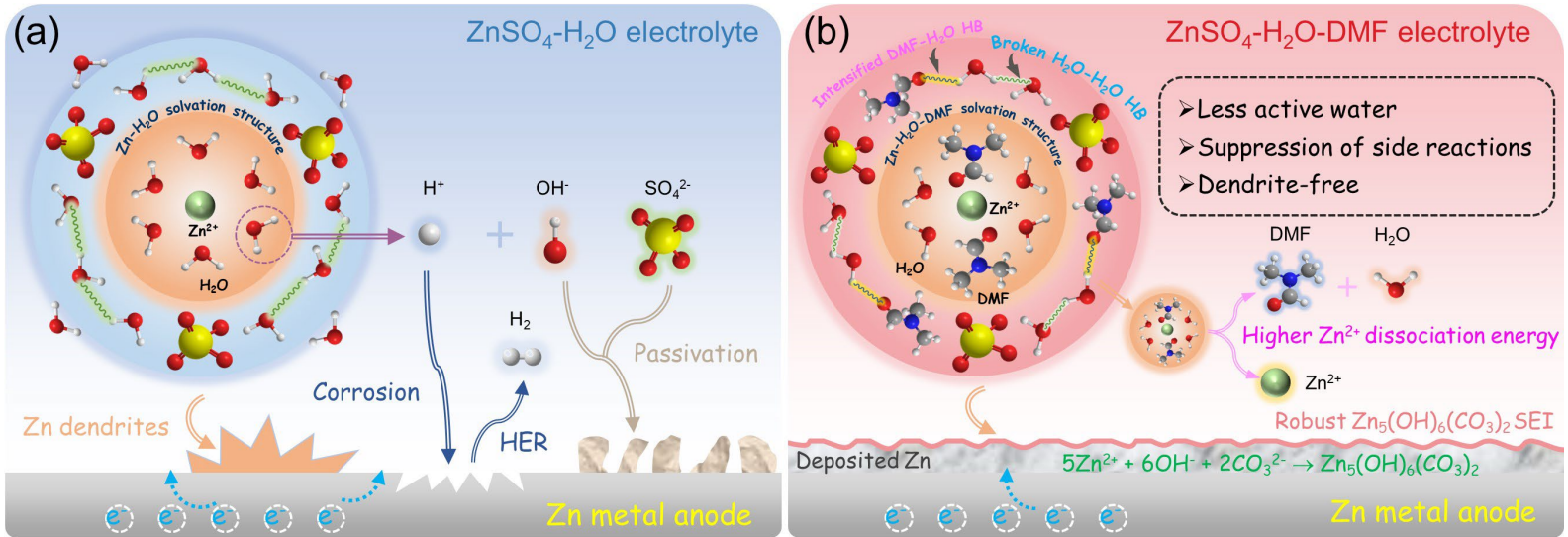

3 Figure 1. Schemes illustrating different reaction processes of $\mathrm{Zn}^{2+}$ solvation structure and 4 corresponding interfacial interaction between $\mathrm{Zn}$ anode surface and electrolyte under (e) $\mathrm{ZnSO}_{4}-\mathrm{H}_{2} \mathrm{O}$ 5 and (b) $\mathrm{ZnSO}_{4}-\mathrm{H}_{2} \mathrm{O}-\mathrm{DMF}$ electrolytes. 
(a)

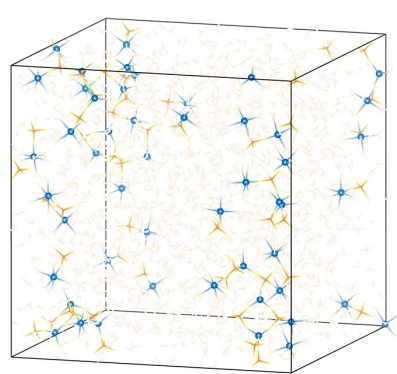

(b)

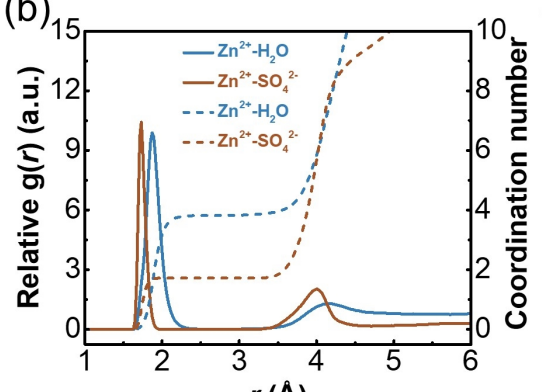

(g)

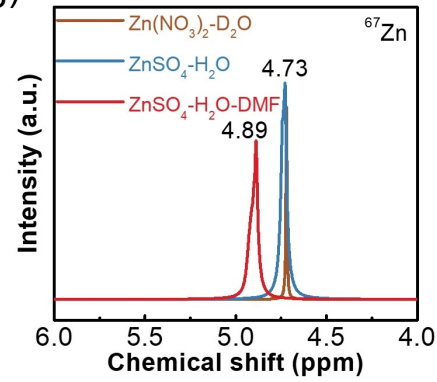

(c)

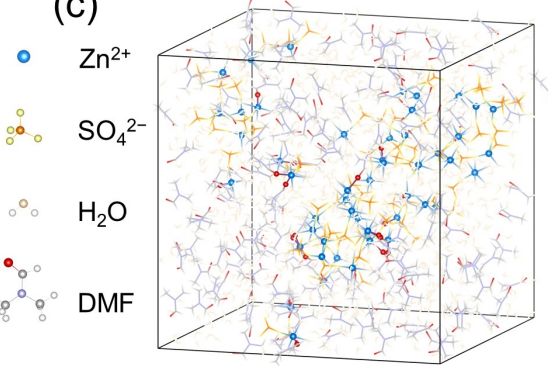

$(\mathrm{e})>$

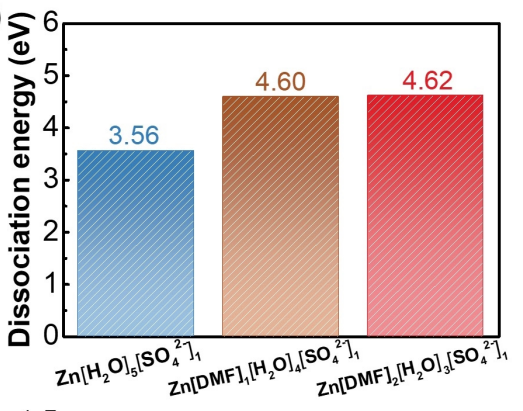

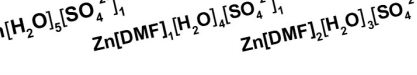

(d)<smiles>[Te]=[Te]</smiles>

(h)

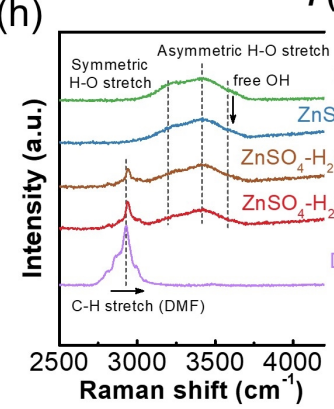

(A)
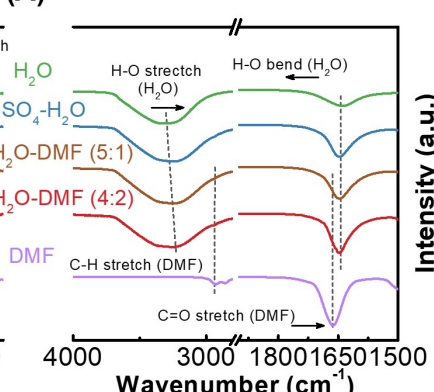

Wavenumber $\left(\mathrm{cm}^{-1}\right)$

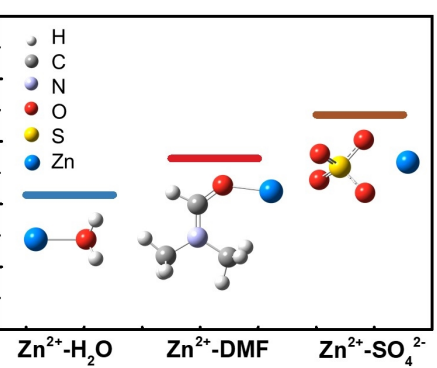

(i)

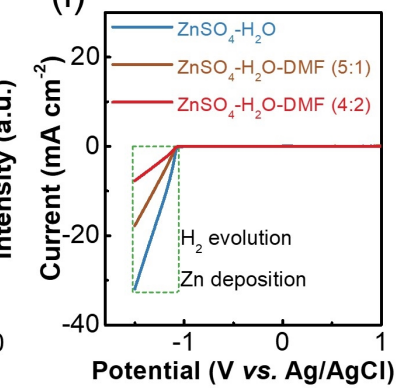

2 Figure 2. Snapshots of (a) $\mathrm{ZnSO}_{4}-\mathrm{H}_{2} \mathrm{O}$ and (c) $\mathrm{ZnSO}_{4}-\mathrm{H}_{2} \mathrm{O}-\mathrm{DMF}$ electrolytes during MD simulations.

3 Radial distribution functions (RDFs) and coordination number distribution functions obtained from

4 MD simulations for (b) $\mathrm{ZnSO}_{4}-\mathrm{H}_{2} \mathrm{O}$ and (d) $\mathrm{ZnSO}_{4}-\mathrm{H}_{2} \mathrm{O}-\mathrm{DMF}$ electrolytes. (e) Dissociation energy of

5 different $\mathrm{Zn}^{2+}[\mathrm{DMF}]_{\mathrm{x}}\left[\mathrm{H}_{2} \mathrm{O}\right]_{\mathrm{y}}\left[\mathrm{SO}_{4}{ }^{2-}\right]_{\mathrm{z}}$ complexes. (f) Relative binding energy for $\mathrm{Zn}^{2+}$ with different

6 species obtained from DFT calculations. (g) ${ }^{67} \mathrm{Zn}$ NMR spectra of $\mathrm{ZnSO}_{4}-\mathrm{H}_{2} \mathrm{O}$ and $\mathrm{ZnSO}_{4}-\mathrm{H}_{2} \mathrm{O}-\mathrm{DMF}$

7 electrolytes. (h) Raman (left) and FTIR (right) spectra of $\mathrm{H}_{2} \mathrm{O}$, DMF, and different electrolytes. (i)

$8 \quad$ LSV response curves of different electrolytes at $0.5 \mathrm{mV} \mathrm{s}^{-1}$. 
(a)

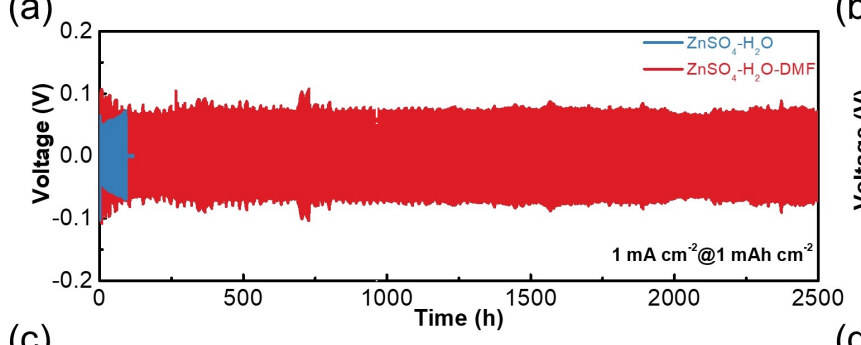

(c)

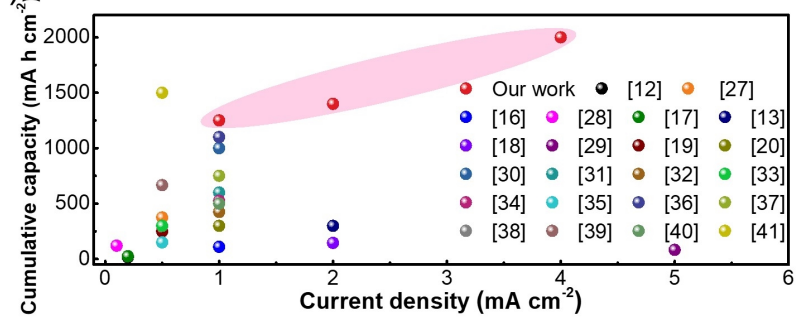

(e)

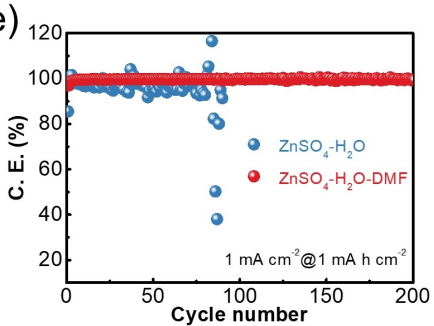

(f)

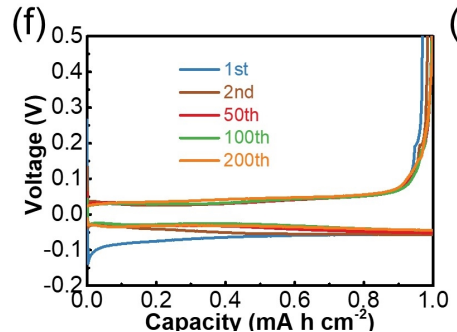

(b)

(d)

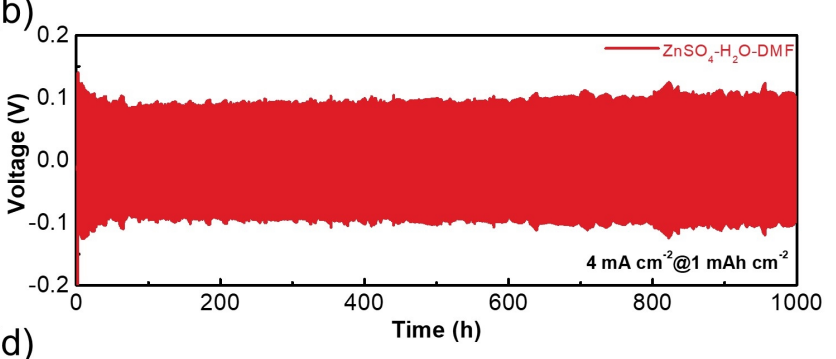

(d)

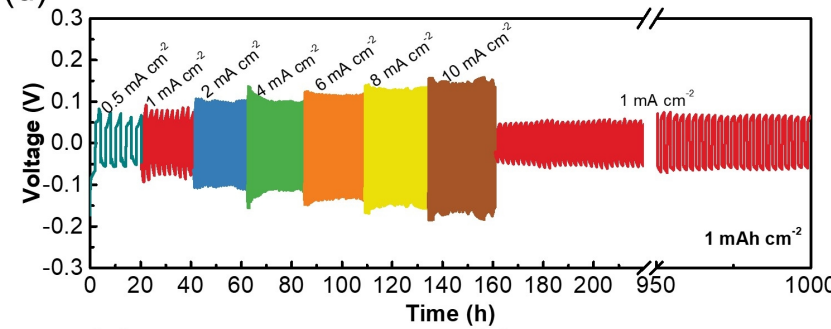

(g)

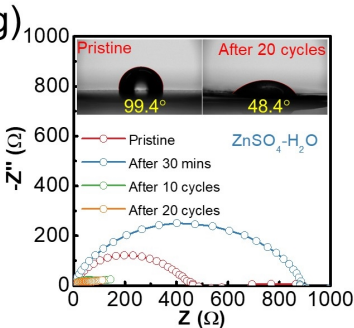

Figure 3. Cycling performance of $\mathrm{Zn} \| \mathrm{Zn}$ symmetric cells in different electrolytes at (a) $1 \mathrm{~mA} \mathrm{~cm}^{-2}$ and (b) $4 \mathrm{~mA} \mathrm{~cm}^{-2}$ for $1 \mathrm{~mA} \mathrm{~h} \mathrm{~cm}{ }^{-2}$. The voltage increase in (a) at around $700 \mathrm{~h}$ is caused by the temperature drop due to power failure of the temperature-controlled equipment. (c) Comparison of the cumulative capacity with recently reported $\mathrm{Zn}$ anodes using optimization strategies. (d) Rate performance of $\mathrm{Zn} \| \mathrm{Zn}$ symmetric cell in $\mathrm{ZnSO}_{4}-\mathrm{H}_{2} \mathrm{O}-\mathrm{DMF}$ at various current densities. (e) $\mathrm{CE}$ of $\mathrm{Zn}$ plating/stripping on $\mathrm{Cu}$ foil in different electrolytes and (f) the corresponding charge-discharge profiles in $\mathrm{ZnSO}_{4}-\mathrm{H}_{2} \mathrm{O}-\mathrm{DMF}$ electrolyte at $1 \mathrm{~mA} \mathrm{~cm}^{-2}$ for $1 \mathrm{~mA} \mathrm{~h} \mathrm{~cm}{ }^{-2}$. EIS of $\mathrm{Zn} \| \mathrm{Zn}$ symmetric cells in $(\mathrm{g})$

$9 \mathrm{ZnSO}_{4}-\mathrm{H}_{2} \mathrm{O}$ and (h) $\mathrm{ZnSO}_{4}-\mathrm{H}_{2} \mathrm{O}-\mathrm{DMF}$ before cycle, rest $30 \mathrm{~min}$, and after cycling (insertion are the 10 contact angles before and after 20 cycles). 


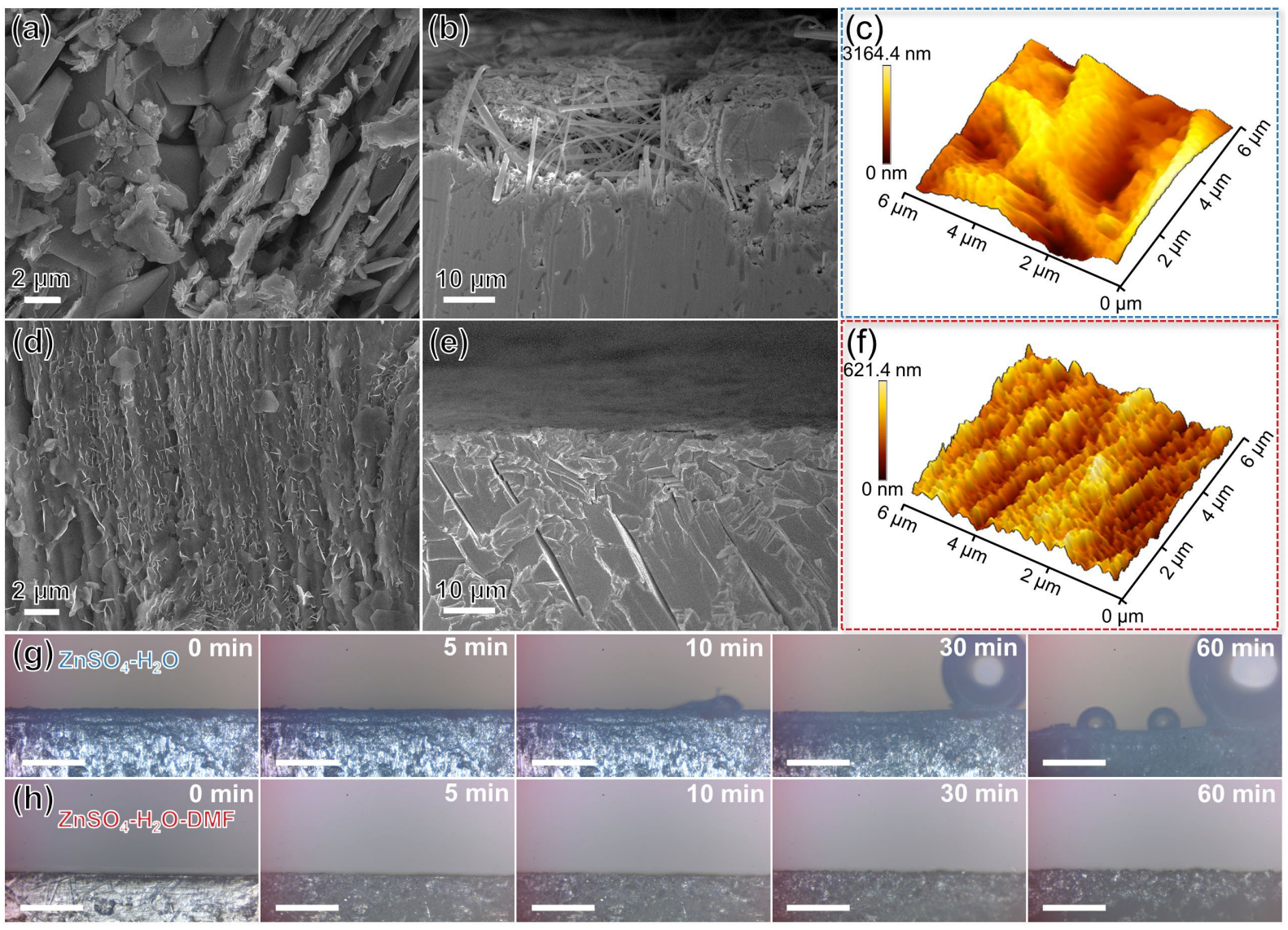

2 Figure 4. SEM images of $\mathrm{Zn}$ anodes after 20 cycles in (a-b) $\mathrm{ZnSO}_{4}-\mathrm{H}_{2} \mathrm{O}$ and (d-e) $\mathrm{ZnSO}_{4}-\mathrm{H}_{2} \mathrm{O}-\mathrm{DMF}$.

3 AFM images of $\mathrm{Zn}$ anodes after 20 cycles in (c) $\mathrm{ZnSO}_{4}-\mathrm{H}_{2} \mathrm{O}$ and (f) $\mathrm{ZnSO}_{4}-\mathrm{H}_{2} \mathrm{O}-\mathrm{DMF}$. Operando

4 optical images of $\mathrm{Zn}$ anodes in (g) $\mathrm{ZnSO}_{4}-\mathrm{H}_{2} \mathrm{O}$ and (h) $\mathrm{ZnSO}_{4}-\mathrm{H}_{2} \mathrm{O}-\mathrm{DMF}$ observed in symmetric

5 transparent cells cycled at $10 \mathrm{~mA} \mathrm{~cm}^{-2}$ (the scale bar is $200 \mu \mathrm{m}$ in each image). 

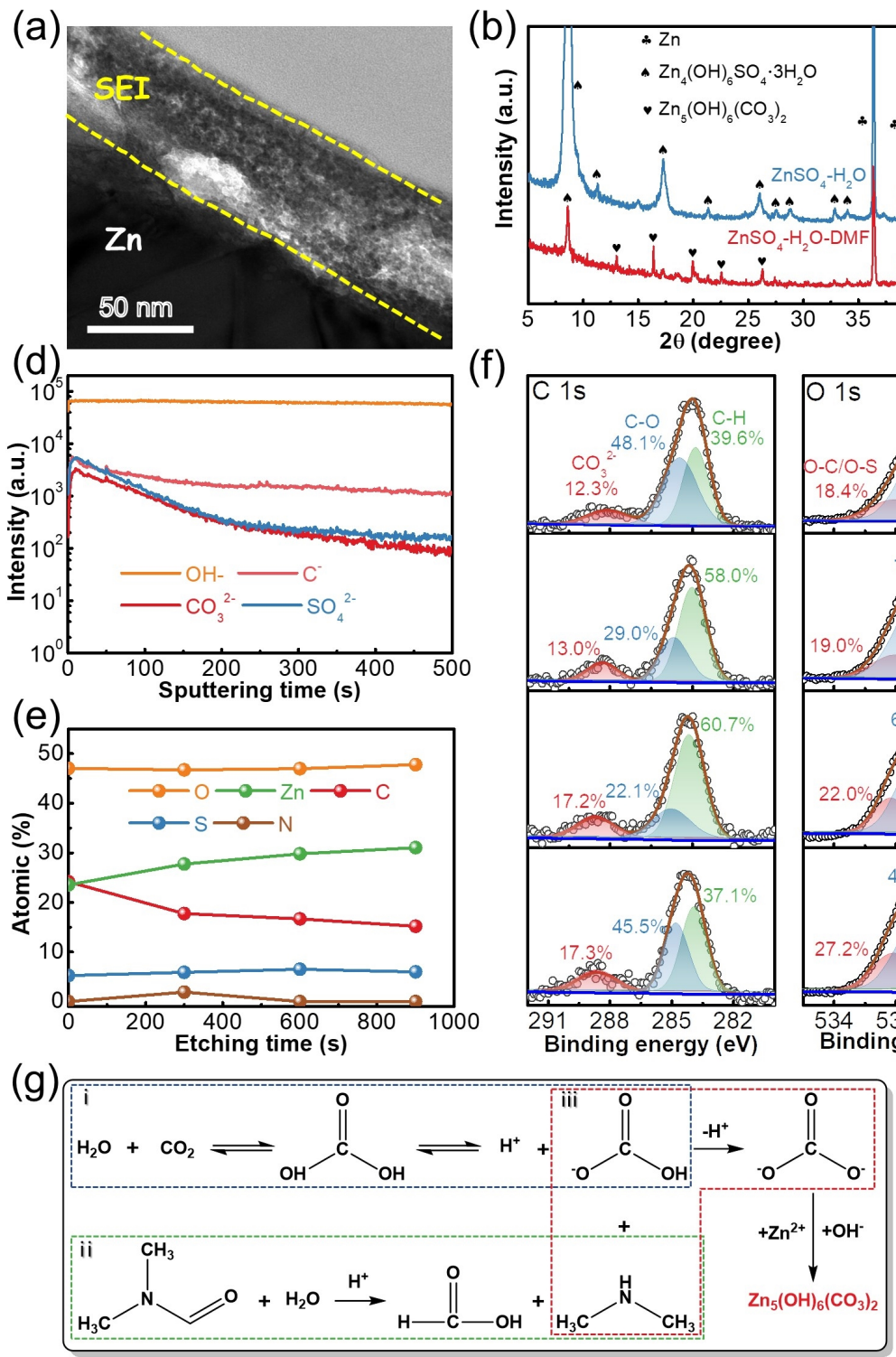

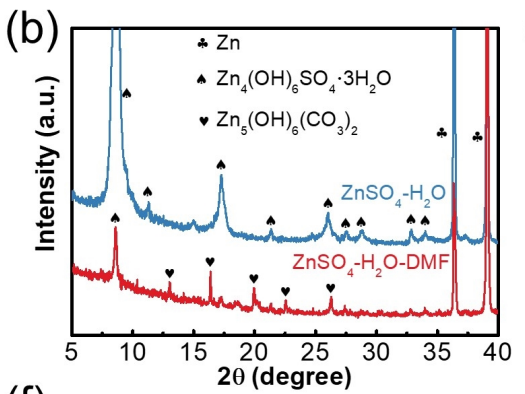

(f)

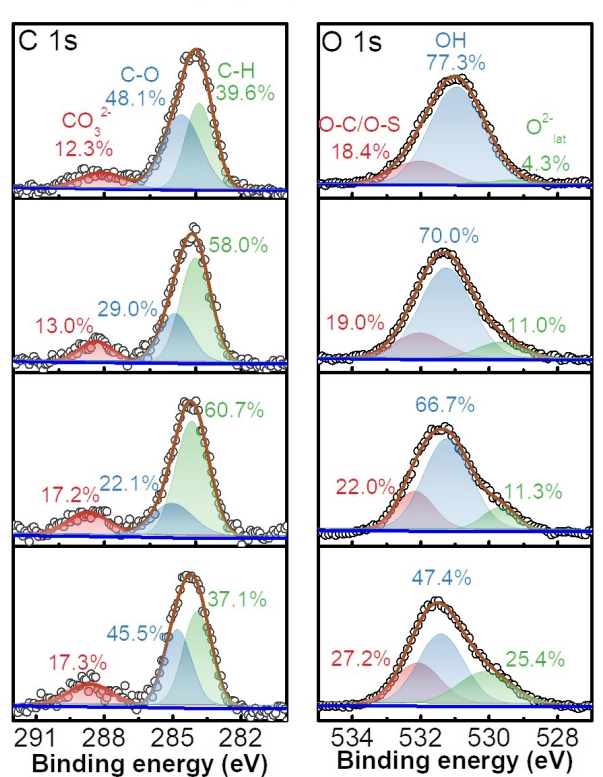

(h)

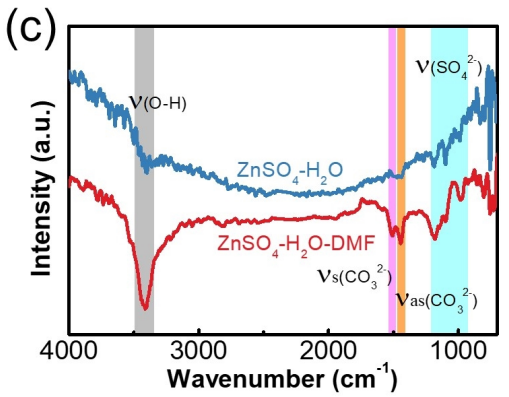

Wavenumber $\left(\mathrm{cm}^{-1}\right)$

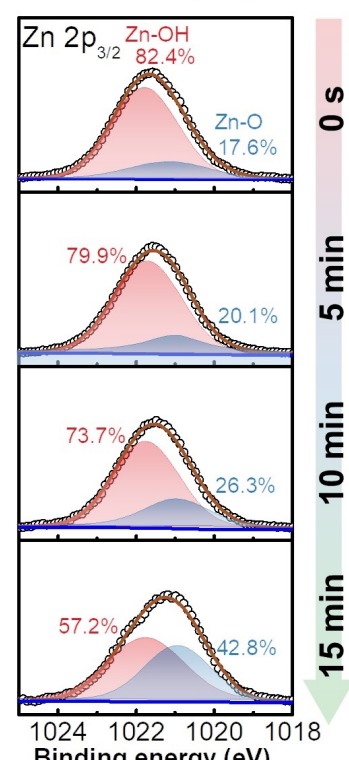

Binding energy (eV)

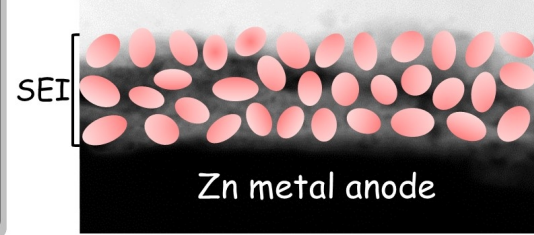

2 Figure 5. (a) TEM image of $\mathrm{Zn}$ anode surface after 20 cycles in $\mathrm{ZnSO}_{4}-\mathrm{H}_{2} \mathrm{O}-\mathrm{DMF}$. (b) XRD patterns and (c) FTIR spectra of $\mathrm{Zn}$ anodes after 20 cycles in $\mathrm{ZnSO}_{4}-\mathrm{H}_{2} \mathrm{O}$ and $\mathrm{ZnSO}_{4}-\mathrm{H}_{2} \mathrm{O}-\mathrm{DMF}$. (d) TOF-

4 SIMS analysis of $\mathrm{Zn}$ anode surface after 20 cycles in $\mathrm{ZnSO}_{4}-\mathrm{H}_{2} \mathrm{O}-\mathrm{DMF}$. (e) Atomic composition of

5 the SEI on $\mathrm{Zn}$ anode surface after 20 cycles in $\mathrm{ZnSO}_{4}-\mathrm{H}_{2} \mathrm{O}-\mathrm{DMF}$. (f) XPS spectra of C $1 \mathrm{~s}$, O $1 \mathrm{~s}$, and

$6 \mathrm{Zn} \mathrm{2} \mathrm{p}_{3 / 2}$ after $\mathrm{Ar}^{+}$sputtering with different times. (g) Formation mechanism and (h) schematic diagram

7 of proposed $\mathrm{Zn}_{5}(\mathrm{OH})_{6}\left(\mathrm{CO}_{3}\right)_{2}$-contained SEI. 
(a)

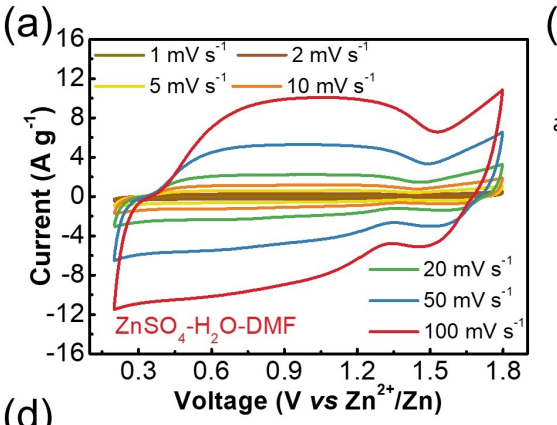

(d)
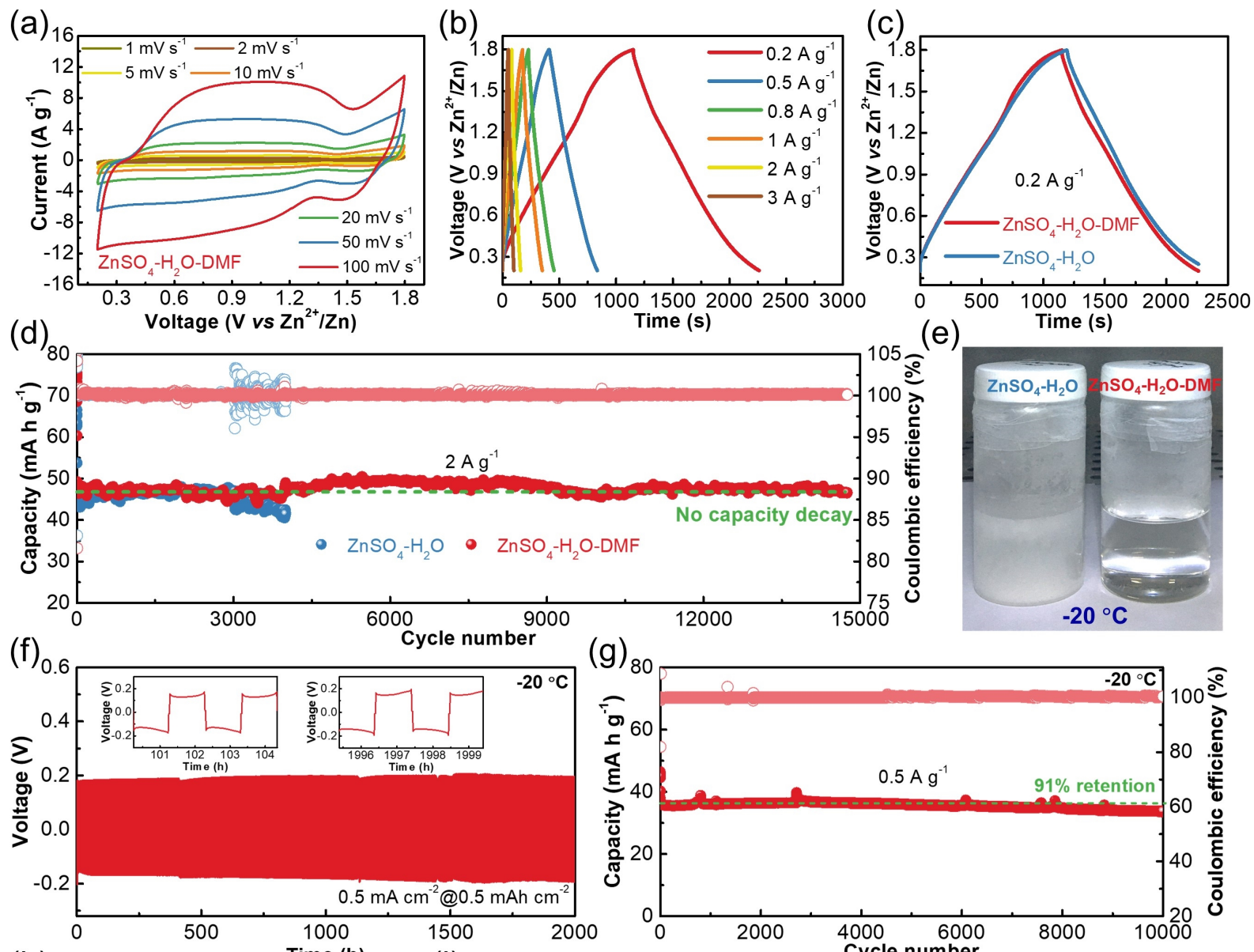

(e) Time (s)

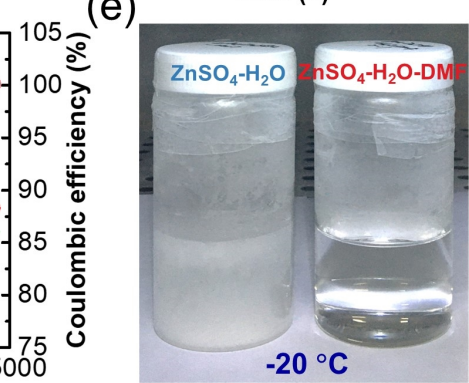

(h)
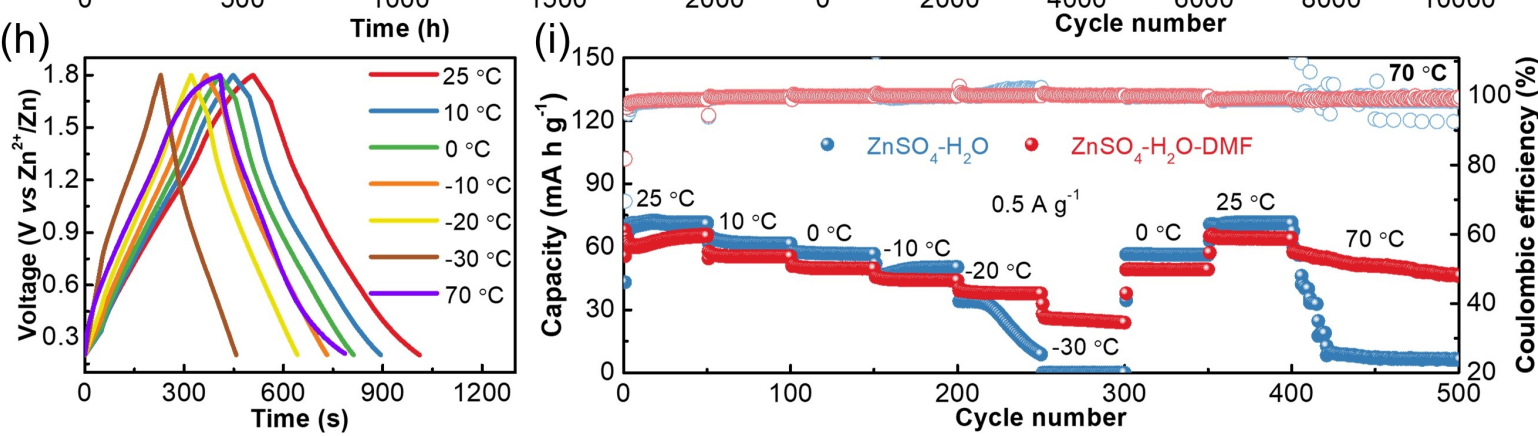

Figure 6. Electrochemical performances of HZICs with different electrolytes using the AC electrodes as a working electrode and the $\mathrm{Zn}$ foil as the counter electrode at wide operating temperatures. (a) $\mathrm{CV}$ curves of HZICs in $\mathrm{ZnSO}_{4}-\mathrm{H}_{2} \mathrm{O}-\mathrm{DMF}$ at different scan rate. (b) Galvanostatic charge-discharge profiles of $\mathrm{HZICs}$ in $\mathrm{ZnSO}_{4}-\mathrm{H}_{2} \mathrm{O}-\mathrm{DMF}$ at various current densities. (c) Galvanostatic charge-discharge profiles of HZICs in different electrolytes at $0.2 \mathrm{~A} \mathrm{~g}^{-1}$. (d) Cycling performance of HZICs with different electrolytes at $2 \mathrm{~A} \mathrm{~g}^{-1}$. (e) The physical state of $\mathrm{ZnSO}_{4}-\mathrm{H}_{2} \mathrm{O}$ and $\mathrm{ZnSO}_{4}-\mathrm{H}_{2} \mathrm{O}-\mathrm{DMF}$ electrolytes at $-20{ }^{\circ} \mathrm{C}$. cycling performance of (f) $\mathrm{Zn} \| \mathrm{Zn}$ symmetric cell at $0.5 \mathrm{~mA} \mathrm{~cm}{ }^{-2}$ and $0.5 \mathrm{~mA} \mathrm{~h}$ $\mathrm{cm}^{-2}$ and (g) HZICs at $0.5 \mathrm{~A} \mathrm{~g}^{-1}$ in $\mathrm{ZnSO}_{4}-\mathrm{H}_{2} \mathrm{O}-\mathrm{DMF}$. (h) Galvanostatic charge-discharge profiles in $\mathrm{ZnSO}_{4}-\mathrm{H}_{2} \mathrm{O}-\mathrm{DMF}$ tested at $0.5 \mathrm{~A} \mathrm{~g}^{-1}$ and various temperatures. (i) The temperature fluctuation test for HZICs at $0.5 \mathrm{~A} \mathrm{~g}^{-1}$. 


\section{Supplementary Files}

This is a list of supplementary files associated with this preprint. Click to download.

- SupplementaryMovie1.mp4

- SINC.docx

- SupplementaryMovie2.mp4 